\title{
Observations and modeling of air quality trends over 1990-2010 across the Northern Hemisphere: China, the United States and Europe
}

\author{
J. Xing ${ }^{1}$, R. Mathur ${ }^{1}$, J. Pleim ${ }^{1}$, C. Hogrefe ${ }^{1}$, C.-M. Gan ${ }^{1}$, D. C. Wong ${ }^{1}$, C. Wei ${ }^{1,2}$, R. Gilliam ${ }^{1}$, and G. Pouliot ${ }^{1}$ \\ ${ }^{1}$ US Environmental Protection Agency, Research Triangle Park, Durham, NC 27711, USA \\ ${ }^{2}$ Multiphase Chemistry Department, Max Planck Institute for Chemistry, 55128 Mainz, Germany
}

Correspondence to: J. Xing (xing.jia@epa.gov, xingjia@tsinghua.org.cn)

Received: 22 August 2014 - Published in Atmos. Chem. Phys. Discuss.: 8 October 2014

Revised: 14 January 2015 - Accepted: 10 February 2015 - Published: 10 March 2015

\begin{abstract}
Trends in air quality across the Northern Hemisphere over a 21-year period (1990-2010) were simulated using the Community Multiscale Air Quality (CMAQ) multiscale chemical transport model driven by meteorology from Weather Research and Forecasting (WRF) simulations and internally consistent historical emission inventories obtained from EDGAR. Thorough comparison with several ground observation networks mostly over Europe and North America was conducted to evaluate the model performance as well as the ability of CMAQ to reproduce the observed trends in air quality over the past 2 decades in three regions: eastern China, the continental United States and Europe.

The model successfully reproduced the observed decreasing trends in $\mathrm{SO}_{2}, \mathrm{NO}_{2}, 8 \mathrm{~h} \mathrm{O} 3$ maxima, $\mathrm{SO}_{4}^{2-}$ and elemental carbon (EC) in the US and Europe. However, the model fails to reproduce the decreasing trends in $\mathrm{NO}_{3}^{-}$in the US, potentially pointing to uncertainties of $\mathrm{NH}_{3}$ emissions. The model failed to capture the 6-year trends of $\mathrm{SO}_{2}$ and $\mathrm{NO}_{2}$ in CN-API (China - Air Pollution Index) from 2005 to 2010, but reproduced the observed pattern of $\mathrm{O}_{3}$ trends shown in three World Data Centre for Greenhouse Gases (WDCGG) sites over eastern Asia. Due to the coarse spatial resolution employed in these calculations, predicted $\mathrm{SO}_{2}$ and $\mathrm{NO}_{2}$ concentrations are underestimated relative to all urban networks, i.e., US-AQS (US - Air Quality System; normalized mean bias $(\mathrm{NMB})=-38 \%$ and $-48 \%$ ), EU-AIRBASE (European Air quality data Base; NMB $=-18$ and $-54 \%$ ) and $\mathrm{CN}$-API (NMB $=-36$ and $-68 \%$ ). Conversely, at the rural network EU-EMEP (European Monitoring and Evaluation Programme), $\mathrm{SO}_{2}$ is overestimated (NMB from 4 to $150 \%$ )
\end{abstract}

while $\mathrm{NO}_{2}$ is simulated well (NMB within $\pm 15 \%$ ) in all seasons. Correlations between simulated and observed $\mathrm{O}_{3}$ wintertime daily $8 \mathrm{~h}$ maxima (DM8) are poor compared to other seasons for all networks. Better correlation between simulated and observed $\mathrm{SO}_{4}^{2-}$ was found compared to that for $\mathrm{SO}_{2}$. Underestimation of summer $\mathrm{SO}_{4}^{2-}$ in the US may be associated with the uncertainty in precipitation and associated wet scavenging representation in the model. The model exhibits worse performance for $\mathrm{NO}_{3}^{-}$predictions, particularly in summer, due to high uncertainties in the gas/particle partitioning of $\mathrm{NO}_{3}^{-}$as well as seasonal variations of $\mathrm{NH}_{3}$ emissions. There are high correlations $(R>0.5)$ between observed and simulated EC, although the model underestimates the EC concentration by $65 \%$ due to the coarse grid resolution as well as uncertainties in the PM speciation profile associated with EC emissions.

The almost linear response seen in the trajectory of modeled $\mathrm{O}_{3}$ changes in eastern China over the past 2 decades suggests that control strategies that focus on combined control of $\mathrm{NO}_{\mathrm{x}}$ and volatile organic compound (VOC) emissions with a ratio of 0.46 may provide the most effective means for $\mathrm{O}_{3}$ reductions for the region devoid of nonlinear response potentially associated with $\mathrm{NO}_{\mathrm{x}}$ or VOC limitation resulting from alternate strategies. The response of $\mathrm{O}_{3}$ is more sensitive to changes in $\mathrm{NO}_{\mathrm{x}}$ emissions in the eastern US because the relative abundance of biogenic VOC emissions tends to reduce the effectiveness of VOC controls. Increasing $\mathrm{NH}_{3}$ levels offset the relative effectiveness of $\mathrm{NO}_{\mathrm{x}}$ controls in reducing the relative fraction of aerosol $\mathrm{NO}_{3}^{-}$formed from declining $\mathrm{NO}_{\mathrm{x}}$ emissions in the eastern US, while the control effectiveness 
was assured by the simultaneous control of $\mathrm{NH}_{3}$ emission in Europe.

\section{Introduction}

The last 2 decades have witnessed significant changes in air pollutant emissions across the globe. Developed countries in North America and Europe have implemented emission reduction measures which have led to a continuous improvement in air quality. Conversely, in developing regions of the world, in Asia in particular, though control actions have been taken, their effectiveness has been outweighed by the sharp increase in emissions resulting from increased energy demand associated with rapidly growing economies and populations. The striking contrast in the trends in air quality between developed and developing countries has been well discussed in recent years (e.g., Richter et al., 2005). It is also believed that the observed "dimming" and "brightening" trends over the past 2 decades is primarily related to the changes of emission patterns over the Northern Hemisphere (e.g., Wild, 2009; Gan et al., 2014). Therefore, an accurate description of the decadal variations in emissions and associated aerosol burden in the atmosphere is the basis of any attempt to explain the causes of decadal changes in surface solar radiations and short-term climate forcing issues arising from human activities.

Improving air quality and protecting the health and welfare of the population is an important goal for any country. Studies on historical trends in air quality can provide an indication of progress in the direction as well as an assessment of future steps towards the goal. On the basis of long-term records, the effectiveness of past or current control policy can be evaluated and suitable control strategies can be designed for the future. In Europe and North America, several monitoring networks have been in operation for decades and observational records available at some networks are long enough to be used in trends analysis studies (e.g., Sickles and Shadwick, 2007). Such records are vital not only because they reflect the changes in air quality over time, but also because they can be used to evaluate long-term trends in air quality arising from estimated changes in historical emissions, simulated by air quality models. Colette et al. (2011) analyzed the air quality trends during 1998-2007 over Europe by using observations of European Monitoring and Evaluation Programme (EU-EMEP, http://www.emep.int) and the European Air quality data Base (EU-AIRBASE, http://acm.eionet. europa.eu/databases/airbase/) records as well as model simulations. Hogrefe et al. (2009) adjusted 6-year model simulations (2000-2005) by using the observed $\mathrm{PM}_{2.5}$ species concentrations from the observations of Interagency Monitoring of Protected Visual Environments (US-IMPROVE, http://vista.cira.colostate.edu/improve/) and Chemical Speciation Network (CSN) sites in the northeastern US. Trends in $\mathrm{O}_{3}$ concentration and $\mathrm{SO}_{4}^{2-}, \mathrm{NO}_{3}^{-}$depositions from 1988 to 2005 simulated by the same model were also compared with long-term observations (Civerolo et al., 2010; Hogrefe et al., 2011). However, due to the large computational cost, very few studies have examined the decadal trend in air pollution over large regions such as northern hemisphere. Koumoutsaris and Bey (2012) evaluated the global model performance of $\mathrm{O}_{3}$ trends simulation (1991-2005) through comparison with long-term observed records from EMEP, the World Data Centre for Greenhouse Gases (WDCGG, http://ds.data.jma.go.jp/gmd/wdcgg/) and the Clean Air Status and Trends Network (US-CASTNET, http://epa. gov/castnet/). Long-term records of lower troposphere $\mathrm{O}_{3}$ concentrations from selected sites which are believed to represent baseline conditions in Europe (Logan et al., 2012) and the US (Parrish et al., 2009, 2012) were used to make quantitative comparisons of simulation results from three chemistry-climate models (NCAR CAM-chem, GFDL-CM3 and GISS-E2-R) (Parrish et al., 2014). To date, however, limited attempts have been made to systematically assess longterm trends in multiple linked atmospheric pollutants (oxidants, particles and acidifying substances) across regional to hemispheric scales.

As a regional chemistry transport model (CTM), the Community Multiscale Air Quality (CMAQ) modeling (version 5.0) system (Binkowski and Roselle, 2003; Byun and Schere, 2006; Foley et al., 2010) has previously been successfully applied for several quality studies over North America (Eder and Yu, 2006; Appel et al., 2007, 2008; Mathur et al., 2008), Europe (Matthias et al., 2012; Kukkonen et al., 2012) and eastern Asia (Yamaji et al., 2006; Wang et al., 2011a; Xing et al., 2011a). However, the need for time-varying lateral boundary conditions (LBCs) which are usually derived from global CTM simulations limits its applications in trend analysis over decades. Recently, the applicability of CMAQ model has been successfully extended to hemispheric scales (Mathur et al., 2012, 2014), so that the application of hemispheric CMAQ provides a consistent approach to generate LBCs for nested regional domains employing finer resolution.

Changing emission patterns across the globe over the past 2 decades have influenced background air pollution levels for different regions across the Northern Hemisphere. To examine air quality trends in different regions over the Northern Hemisphere, we used a multiscale chemical transport model (i.e., CMAQ) driven by historical emission inventories and a meteorological data set to simulate air quality from 1990 to 2010 . The ability of the multiscale model to reproduce observed trends over the Northern Hemisphere, including North America, Europe and eastern Asia, was assessed. A brief description of the model configuration, emission processing and observations is given in Sect. 2. The evaluation of model performance through comparison with long-term observation records is presented in Sect. 3.1. The trends in both observed 
and simulated air quality are provided in Sect. 3.2 and further discussed in Sect. 4.

\section{Method}

\subsection{Model configuration}

Unlike the traditional regional studies with CMAQ, this study used a simulation domain extended to cover the entire Northern Hemisphere with a grid of $108 \mathrm{~km} \times 108 \mathrm{~km}$ resolution and 44 vertical layers of variable thickness between the surface and $50 \mathrm{mb}$ (Mathur et al., 2012, 2014). We selected three sub-regions, i.e., eastern China $\left(20-40^{\circ} \mathrm{N}\right.$, $\left.100-125^{\circ} \mathrm{E}\right)$, eastern US $\left(28-50^{\circ} \mathrm{N}, 100-70^{\circ} \mathrm{W}\right)$ and Europe $\left(35-65^{\circ} \mathrm{N}, 10^{\circ} \mathrm{W}-30^{\circ} \mathrm{E}\right)$, for further analysis and comparison with measurements. These three sub-regions are parts of the original Northern Hemispheric domain and no nested simulations were conducted.

The meteorological inputs for 21-year Weather Research and Forecasting (WRF) simulations were derived from the NCEP/NCAR Reanalysis data which has $2.5^{\circ}$ spatial and $6 \mathrm{~h}$ temporal resolution. NCEP ADP Operational Global Surface Observations were used for surface reanalysis which is used for indirect soil moisture and temperature nudging (Pleim and Xiu, 2003; Pleim and Gilliam, 2009) in the Pleim-Xiu Land Surface Model (PX LSM) (Pleim and Xiu, 1995; Xiu and Pleim, 2001). The WRF configurations also used MODIS land-use types with 20 categories, RRTMg shortwave and longwave radiation scheme (Iacono et al., 2008), and the ACM2 planetary boundary layer (PBL) model (Pleim, 2007a, b). WRF performance for the simulation of hourly surface temperature $(T)$, relative humidity and wind speed and direction was evaluated through comparison with observations from NOAA's National Climatic Data Center (NCDC) Integrated Surface Data (ISD, with lite format) which provides hourly (or with $3 \mathrm{~h}$ interval) meteorological observations over a long historical period across the globe. The mean bias of $T$, wind speed and direction over the simulation domain is $-0.4 \mathrm{~K}, 0.4 \mathrm{~m} \mathrm{~s}^{-1}$ and $-3^{\circ}$, respectively, over the 21-year period. The ranges of biases meet the model performance criteria recommended by Emery et al. (2001) for retrospective regional-scale model applications which are $\leq \pm 0.5 \mathrm{~K}, \leq \pm 0.5 \mathrm{~m} \mathrm{~s}^{-1}$ and $\leq \pm 10^{\circ}$, respectively, suggesting that meteorology simulations in this study are acceptable. The evaluation of WRF performances ensures that there is no significant bias in the meteorological fields used in the coupled model.

\subsection{Emission inventories from 1990 to 2010}

Figure 1 presents a flow chart of the approach to emission processing employed in creating model inputs spanning the 21-year period. EDGAR (Emission Database for Global Atmospheric Research, version 4.2) (European Commission, 2011) provides a consistent global emission inventory for
1970-2008 for 17 anthropogenic sectors at a $0.1^{\circ} \times 0.1^{\circ}$ resolution. In this study, we used year-specific EDGAR emissions for the period 1990-2008. Estimates for 2009 and 2010 were derived from projections based on the three most recent references for the United States (Xing et al., 2013), Europe (EEA, 2012) and China (He, 2012). In Europe and North America, pollutant emissions, $\mathrm{SO}_{2}$ and $\mathrm{NO}_{\mathrm{x}}$ in particular, have seen continuous reductions during 1990-2010 (refer to Fig. 2). In contrast, $\mathrm{NO}_{\mathrm{x}}$ and volatile organic compound (VOC) emissions in China have continuously increased, while $\mathrm{SO}_{2}$ increased during 1990-2006 then decreased from 2007 to 2010 due to more recent strict controls (Zhao et al., 2013; Wang et al., 2014). Emissions in other areas during 2009-2010 were kept the same as the 2008 values. Additionally, since EDGARv4.2 provides only $\mathrm{PM}_{10}$ emissions, $\mathrm{PM}_{2.5}$ emissions were estimated by deriving the ratio of $\mathrm{PM}_{2.5}$ to $\mathrm{PM}_{10}$ from the 2000-2005 EDGAR HTAP (Hemispheric Transport of Air Pollution, version 1) inventory (Janssens-Maenhout et al., 2012), which provides both $\mathrm{PM}_{10}$ and $\mathrm{PM}_{2.5}$ emissions, and then applying this ratio to split EDGARv4.2 $\mathrm{PM}_{10}$ emissions into $\mathrm{PM}_{2.5}$ and $\mathrm{PM}_{2.5-10}$. Biogenic VOC and lightning $\mathrm{NO}_{\mathrm{x}}$ emissions were obtained from GEIA (Global Emission Inventory Activity) (Guenther et al., 1995; Price et al., 1997) and were kept the same for all years during 1990-2010. The $0.1^{\circ}$ resolution gridded data were spatially allocated to the CMAQ grid ensuring conservation of mass. Vertical profiles for anthropogenic sectors and lightning were based on Simpson et al. (2003) and Ott et al. (2010), respectively. The annual mean emissions in each sector were distributed into each hour for each simulated day using the EDGAR default temporal profiles which are primarily based on western European data (http://themasites.pbl.nl/tridion/en/themasites/ edgar/documentation/content/Temporal-variation.html).

Emissions of $\mathrm{PM}_{2.5}$ and non-methane volatile organic compounds (NMVOCs) were further speciated into AERO6 and CB05 species based on default profiles in the Sparse Matrix Operator Kernel Emissions modeling system (SMOKE, http://cmascenter.org/smoke/), which is primarily based on data for the United States. Uncertainties are expected when region-specific temporal and speciation profiles are applied to all other counties; however, this approach is reasonable given the lack of any additional information. Further improvement and data are needed to develop more representative profiles for other countries.

\subsection{Observed long-term trends}

Table 1 summarizes the data set used in this study, which includes three networks in the United States, i.e., Air Quality System, (US-AQS, http://www.epa.gov/ttn/airs/airsaqs/), US-CASTNET and US-IMPROVE; two networks in Europe, i.e., EU-EMEP and EU-AIRBASE; one in China, CN-API (Air Pollution Index), and one global network, WDCGG. Among these, records of US-CASTNET, US-IMPROVE and 


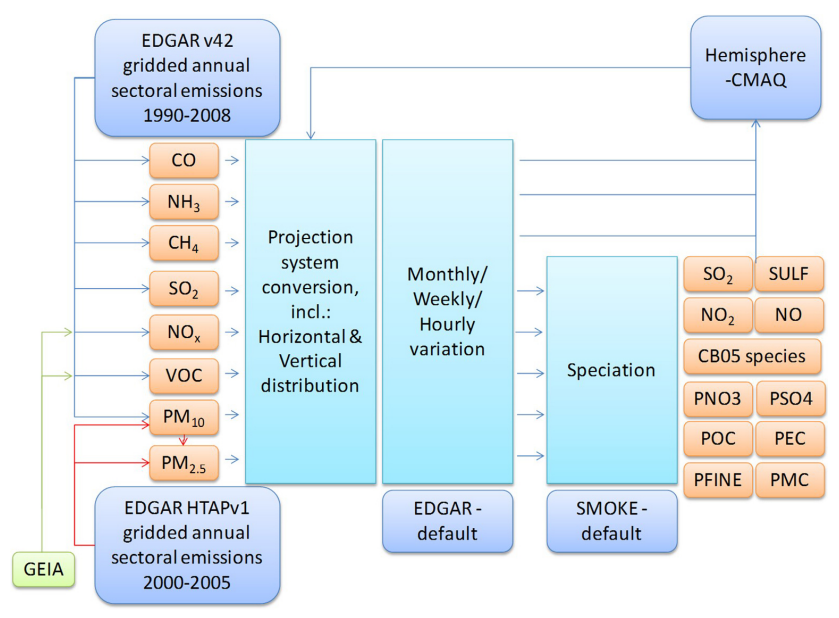

Figure 1. Processes of gridded emissions for Northern Hemispheric WRF-CMAQ simulation.

EU-EMEP are specifically designed for trend assessments since most of their sites are located in rural background areas in order to represent regional atmospheric pollution. Sites in US-AQS and EU-AIRBASE are typically closer to urban areas and may be impacted by local pollution and features sub-grid to the model resolution, thus representative of much smaller regions. To obtain a more valid analysis, the US-AQS and EU-AIRBASE data were averaged over the $108 \mathrm{~km}$ grid cells before comparison with the model. $\mathrm{CN}$-API is the average of observed air pollutant concentrations from urban monitoring sites in each city and represents records in seven Chinese cities (i.e., Beijing, Shanghai, Guangzhou, Xi' an, Wuhan, Guiyang and Guilin, which are located in the North China Plain, Yangtze River delta, Pearl River delta, northwest China, central China, southwest China and southern China, respectively) where long-term observations are available starting from 2005. (Jiang et al., 2004; Wang et al., 2011a). In addition, three selected WDCGG sites were used for $\mathrm{O}_{3}$ trends analysis in eastern Asia. Only data at sites that covered the $75 \%$ of entire 21 -year period (i.e., at least 18 available years with $>75 \%$ coverage for each year) are considered except in the case of CN-API which was only recently setup in the early 2000s and in the case of US-CASTNET (for $\mathrm{O}_{3}$ only) because most sites have no $\mathrm{O}_{3}$ records in winter (criteria set as at least 15 available years with $>75 \%$ coverage from March to November for each year). Details about the time-period covered, the number of sites selected for analysis and the record frequency for each network can be found in Table 1. Model results at each monitor location were matched in time to the available record; thus, model data were not considered during periods of missing observations, in either the statistical evaluation or in the trend analysis.

To evaluate the model's performance, model-observed comparisons were conducted by network and pollutant. Five statistical measures, correlation coefficient $(R)$, mean bias (MB), normalized mean bias (NMB), root mean squared error (RMSE) and normalized mean error (NME), are employed for evaluation. In consideration of the limited length of record, this study only focuses on linear trends (Colette et al., 2011). The linear least square fit method was employed, and significance of trends was examined with a Student $t$ test at the $95 \%$ confidence level $(p=0.05)$.

\section{Results}

\subsection{Model performance}

Table 2 summaries the statistics of model performance for gaseous species (Table 2a) and fine particles (Table 2b).

\subsection{1 $\mathrm{SO}_{2}$ and $\mathrm{NO}_{2}$ concentration}

Model performance characteristics for $\mathrm{SO}_{2}$, primarily emitted from point sources, can largely be attributed to artificial dilution effects over the large grid volumes employed here. As expected, a hemispherical simulation with relatively coarse spatial resolution is unable to accurately capture the peak values. As seen in Table $2 \mathrm{a}, \mathrm{SO}_{2}$ is underestimated for all urban networks characterized by higher concentrations than rural networks, i.e., US-AQS underestimated by $38 \%$, EU-AIRBASE by $17 \%$ and CN-API by $36 \%$. For the rural network EU-EMEP, $\mathrm{SO}_{2}$ is overestimated in all seasons (4-150\%). A small bias is evident for US-CASTNET annual concentrations since the overestimation in fall is compensated by the underestimation in spring and winter.

Similar performance is noted for simulated $\mathrm{NO}_{2}$. The model significantly underestimates $\mathrm{NO}_{2}$ at urban networks: US-AQS by $48 \%$, EU-AIRBASE by $54 \%$ and CN-API by $68 \%$. However, much better performance is noted at sites in the rural network EU-EMEP with bias within $\pm 15 \%$ in all seasons. Though the model-observation correlation coefficients $(R)$ are low for EU-AIRBASE $(0.4)$ and CNAPI (0.08) on annual basis, the MB in EU-AIRBASE $\left(-13.9 \mu \mathrm{g} \mathrm{m}^{-3}\right)$ is comparable with previous modeling as reported by Colette et al. (2011) $\left(-6.5\right.$ to $\left.-18.1 \mu \mathrm{g} \mathrm{m}^{-3}\right)$ and the magnitude of NMB in CN-API $(67.5 \%)$ is comparable with Wang et al. (2009) (-61.2 to $-81.3 \%)$ but in the opposite direction. It is expected that the performance should be better when simulations are conducted with finer horizontal resolution and with more accurate spatially resolved emissions.

\subsection{2 $\mathrm{O}_{3}$ concentration}

Model performance for $\mathrm{O}_{3}$ is examined through comparisons of seasonal or annual maxima of the daily maxima $8 \mathrm{~h}$ (DM8) average or $1 \mathrm{~h}$ values since those are the metrics most relevant to air quality standards and health assessments. 
(a) $\mathrm{SO}_{2}$

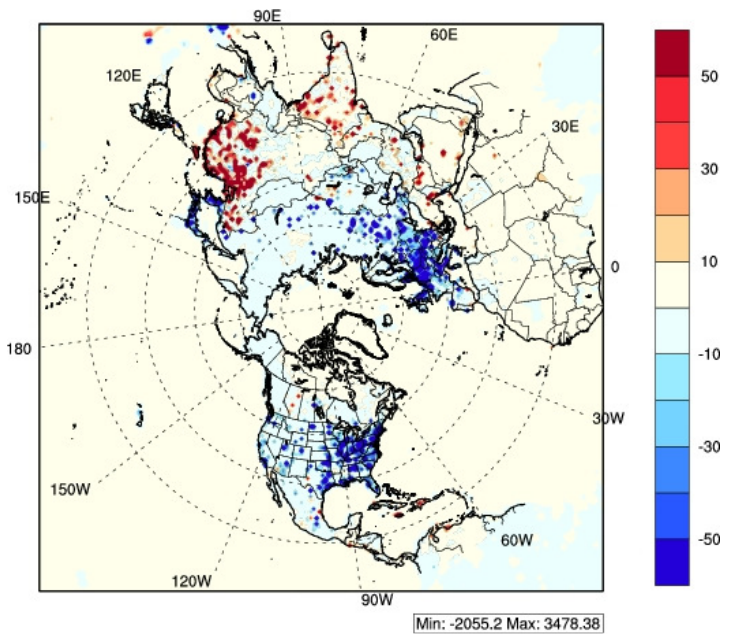

(c) NMVOC

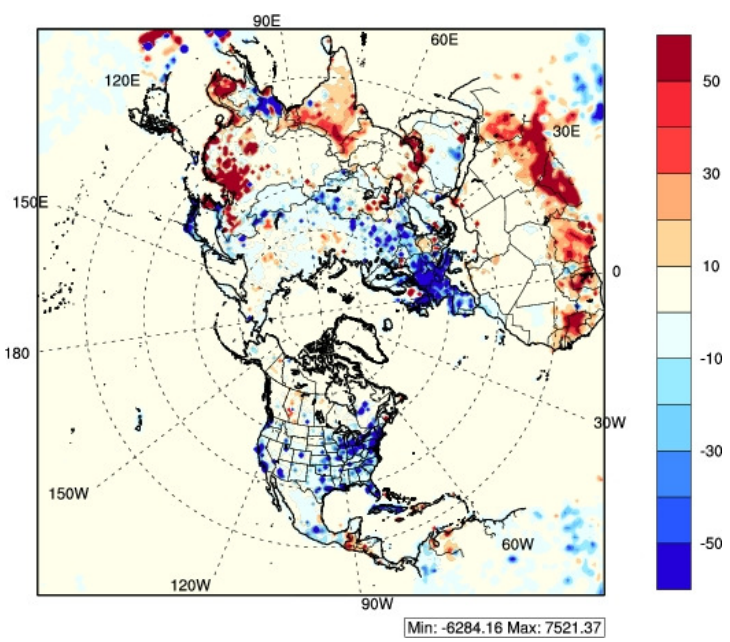

(b) $\mathrm{NO}_{\mathrm{x}}$

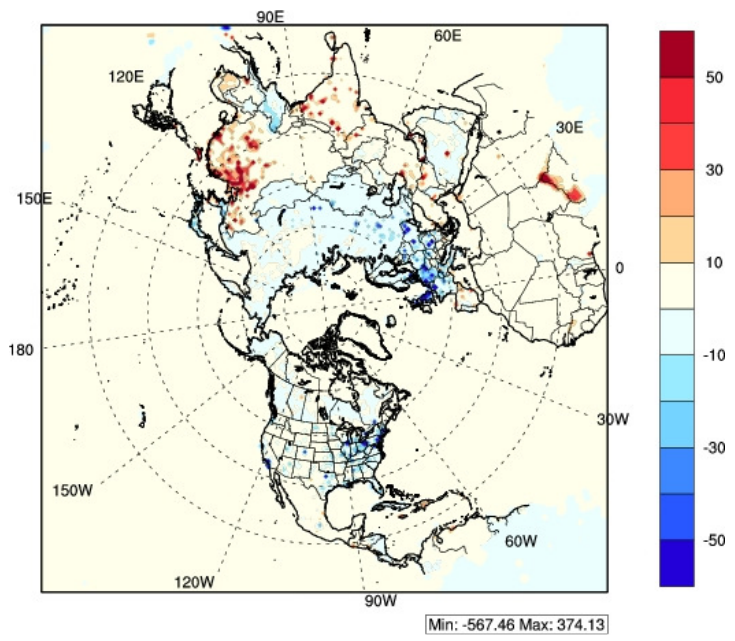

(d) $\mathrm{NH}_{3}$

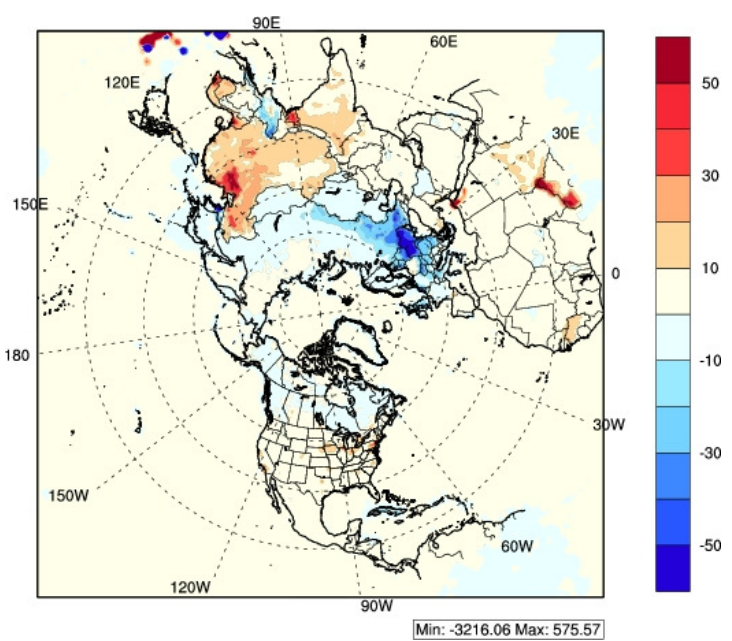

Figure 2. EDGAR emission trend over 1990 to 2010 for $\mathrm{SO}_{2}, \mathrm{NO}_{\mathrm{x}}$, NMVOC and $\mathrm{NH}_{3}\left(\mathrm{~kg} \mathrm{~km}^{-2} \mathrm{yr}^{-1}\right.$, computed on the basis of annual means over the 1990-2010 period with a linear least square fit method).

Correlation coefficients in EU-AIRBASE (0.4) are lower than Colette et al. (2011) (0.6-0.8) because the frequency of the observed record used in this study is annual, and therefore, the correlation coefficients calculated here do not benefit from the fact that the model simulations generally capture the observed seasonal cycle. However, the MB $\left(14.4 \mu \mathrm{g} \mathrm{m}^{-3}\right)$ is comparable with that reported in Colette et al. (2011) $\left(-4.3\right.$ to $\left.18.5 \mu \mathrm{g} \mathrm{m}^{-3}\right)$. Simulations in winter $(R=0.3-0.5)$ have the worst correlation with observations for all networks compared to those in other seasons $(R=0.6-0.8)$. On the other hand, both NMB (-13.6 to $16.9 \%)$ and NME $(<25.9 \%)$ are fairly small in all seasons and comparable with that reported by Zhang et al. (2009) (NMB: -10.6 to $15.9 \%$; NME: $<25.4 \%)$ and Wang et al. (2009) $(|\mathrm{NMB}|<37.9 \%)$.

\subsection{3 $\mathrm{SO}_{4}^{2-}, \mathrm{NO}_{3}^{-}$and $\mathrm{NH}_{4}^{+}$concentration}

$\mathrm{SO}_{4}^{2-}$ which is formed from the oxidation of $\mathrm{SO}_{2}$, is the predominant inorganic aerosol component. In general, $\mathrm{SO}_{4}^{2-}$ concentrations show a strong positive response to the changes in $\mathrm{SO}_{2}$ emissions (Butler and Lakens, 1991), though the $\mathrm{SO}_{2}$ effective cloud oxidation rate can be affected by $\mathrm{NH}_{3}$ (Pandis and Seinfeld, 1989; Tsimpidi et al., 2007). As a secondary species, $\mathrm{SO}_{4}^{2-}$ is widely spread over the region, unlike $\mathrm{SO}_{2}$ which is usually more localized to source areas. As seen in Table 2b, correlation coefficients for $\mathrm{SO}_{4}^{2-}$ simulation $(0.5-0.9)$ are higher than those for $\mathrm{SO}_{2}(0.4-0.8)$. The NMBs for US-CASTNET ( -8 to $-45 \%)$ and US-IMPROVE ( -29 to $22 \%$ ) are comparable with the results reported by Zhang et al. (2009), which are -23 to $22 \%$ and -8 to $16 \%$, Eder 
Table 1. Summary of long-term observations used for trends analysis in this study.

\begin{tabular}{|c|c|c|c|c|c|}
\hline Species & Network & Region & $\begin{array}{l}\text { Number of sites } \\
\text { (at least } 18 \text { years available with } \\
>75 \% \text { annual coverage) }\end{array}$ & $\begin{array}{l}\text { Time } \\
\text { period }\end{array}$ & $\begin{array}{l}\text { Record } \\
\text { frequency }\end{array}$ \\
\hline \multicolumn{6}{|c|}{ Gaseous species } \\
\hline \multirow[t]{5}{*}{$\mathrm{SO}_{2}$} & CASTNET & United States & 38 selected from 133 & 1990-2010 & Weekly \\
\hline & AQS & United States & 280 selected from 1177 & 1990-2010 & Annual \\
\hline & AIRBASE & Europe & 126 selected from 510 & 1990-2010 & Annual \\
\hline & EMEP & Europe & 44 selected from 237 & 1990-2010 & Monthly \\
\hline & API & China & 7 & 2005-2010 & Annual \\
\hline \multirow[t]{4}{*}{$\mathrm{NO}_{2}$} & AQS & United States & 181 selected from 714 & 1990-2010 & Annual \\
\hline & AIRBASE & Europe & 160 selected from 440 & 1990-2010 & Annual \\
\hline & EMEP & Europe & 39 selected from 237 & 1990-2010 & Monthly \\
\hline & API & China & 7 & 2005-2010 & Annual \\
\hline \multirow[t]{4}{*}{$\mathrm{O}_{3}$} & CASTNET* & United States & 25 selected from 133 & 1990-2010 & Daily \\
\hline & AIRBASE & Europe & 147 selected from 315 & 1990-2010 & Annual \\
\hline & EMEP & Europe & 69 selected from 190 & 1990-2010 & Daily \\
\hline & WDCGG & Global (Japan used only) & 3 selected from 102 & 1990-2010 & Hourly \\
\hline \multicolumn{6}{|l|}{ Particles } \\
\hline \multirow[t]{3}{*}{$\mathrm{SO}_{4}^{2-}$} & CASTNET & United States & 38 selected from 133 & 1990-2010 & Weekly \\
\hline & IMPROVE & United States & 27 selected from 197 & 1990-2010 & Semi-weekly \\
\hline & EMEP & Europe & 39 selected from 237 & 1990-2010 & Monthly \\
\hline \multirow{3}{*}{$\mathrm{NO}_{3}^{-}$} & CASTNET & United States & 38 selected from 133 & 1990-2010 & Weekly \\
\hline & IMPROVE & United States & 27 selected from 197 & 1990-2010 & Semi-weekly \\
\hline & EMEP & Europe & 12 selected from 237 & 1990-2010 & Monthly \\
\hline \multirow[t]{2}{*}{$\mathrm{NH}_{4}^{+}$} & CASTNET & United States & 38 selected from 133 & 1990-2010 & Weekly \\
\hline & EMEP & Europe & 6 selected from 237 & $1990-2010$ & Monthly \\
\hline $\mathrm{EC}$ & IMPROVE & United States & 26 selected from 197 & 1990-2010 & Semi-weekly \\
\hline
\end{tabular}

and $\mathrm{Yu}(2006)$, which are -10 and $-5 \%$ on annual level, and Wang et al. (2009) ( $|\mathrm{NMB}|<55 \%)$. Significant $\mathrm{SO}_{4}^{2-}$ underestimation is noted during summer at both US-CASTNET (by $45.2 \%$ ) and US-IMPROVE (by $28.9 \%$ ). Some studies also found similar underprediction in their simulations and they attributed such low biases to the uncertainty in precipitation and overestimation of wet scavenging (Luo et al., 2011; Zhang et al., 2014). However, precipitation simulated in this study is underestimated domain-wide by $4 \%$ (in summer) and $65 \%$ (in winter). Wang et al. (2009) found similar underestimation of precipitation from -31 to $-41 \%$, but $\mathrm{SO}_{4}^{2-}$ was overpredicted because higher $\mathrm{SO}_{2}$ emissions were used. Future investigation of the low bias in predicted $\mathrm{SO}_{4}^{2-}$ is still necessary. Better performance is shown in EU-EMEP, with NMB within $\pm 30 \%$. The difference in sulfate biases between the US networks and the European networks might be associated with the different $\mathrm{SO}_{2}$ biases, i.e., a moderate bias $(\mathrm{NMB}=-9.4 \%)$ in US-CASTNET but a relatively larger bias $(\mathrm{NMB}=+67 \%)$ in EU-EMEP. The transition rate from $\mathrm{SO}_{2}$ to $\mathrm{SO}_{4}^{2-}$ is likely underestimated in both regions, lead- ing to the underestimation of $\mathrm{SO}_{4}^{2-}$ in the US and the better estimates of $\mathrm{SO}_{4}^{2-}$ in Europe.

Worse performance for $\mathrm{NO}_{3}^{-}$prediction is expected because of higher uncertainties in representing the gas/particle partitioning of airborne nitrate (Mathur and Dennis, 2003; Eder and $\mathrm{Yu}, 2006$ ), especially in summer when $\mathrm{SO}_{4}^{2-}$ concentrations are higher and available $\mathrm{NH}_{3}$ preferentially react to form ammonium sulfate, leading to low ambient $\mathrm{NO}_{3}^{-}$ level. Simulated and observed $\mathrm{NO}_{3}^{-}$have the lowest correlations for both US-CASTNET and US-IMPROVE sites ( $R=0.31$ and 0.10 respectively) during summer compared those in other seasons $(\mathrm{R}=0.7)$. Similar magnitudes of NMB ( -56 to $59 \%$ ) and NME (89 to $197 \%$ ) at US-IMPROVE sites were reported by Wang et al. (2009) and Zhang et al. (2009). The underestimation in summer and overestimation in spring/winter are found relative to both CASTNET (NMB: -48 and 93/75\%) and IMPROVE (NMB: -41 and $107 / 95 \%$ ) and comparable to previous CMAQ analysis of Eder and $\mathrm{Yu}(2006)(|\mathrm{NMB}|>40 \%)$. Uncertainties in $\mathrm{NH}_{3}$ emission particularly in the seasonal temporal profile may 
Table 2a. Model performance. Gaseous species.

\begin{tabular}{|c|c|c|c|c|c|c|c|c|c|}
\hline Species & Network & & $\begin{array}{r}\text { Obs } \\
\left(\mu \mathrm{g} \mathrm{m}^{-3}\right)\end{array}$ & $R$ & $\begin{array}{r}\mathrm{MB} \\
\left(\mu \mathrm{g} \mathrm{m}^{-3}\right)\end{array}$ & $\begin{array}{r}\text { NMB } \\
(\%)\end{array}$ & $\begin{array}{r}\text { RMSE } \\
\left(\mu \mathrm{g} \mathrm{m}^{-3}\right)\end{array}$ & $\begin{array}{r}\text { NME } \\
(\%)\end{array}$ & $\begin{array}{r}N \\
\text { pairs }\end{array}$ \\
\hline \multirow{13}{*}{$\mathrm{SO}_{2}$} & \multirow[t]{5}{*}{ US-CASTNET } & Spring & 5.0 & 0.73 & -1.1 & -21.8 & 3.2 & 72.4 & 2316 \\
\hline & & Summer & 3.3 & 0.74 & 0.2 & 5.3 & 2.4 & 93.4 & 2352 \\
\hline & & Fall & 4.5 & 0.78 & 1.6 & 36.0 & 3.8 & 118.0 & 2348 \\
\hline & & Winter & 8.1 & 0.67 & -2.7 & -33.4 & 6.0 & 81.7 & 2317 \\
\hline & & Annual & 5.2 & 0.67 & -0.5 & -9.4 & 4.1 & 91.5 & 9333 \\
\hline & US-AQS & Annual & 12.2 & 0.2 & -4.6 & -37.5 & 10.6 & 135.3 & 2628 \\
\hline & EU-AIRBASE & Annual & 8.7 & 0.3 & -1.5 & -17.7 & 9.6 & 98.8 & 580 \\
\hline & \multirow[t]{5}{*}{ EU-EMEP } & Spring & 2.4 & 0.43 & 2.0 & 82.2 & 5.0 & 239.8 & 2399 \\
\hline & & Summer & 1.6 & 0.44 & 2.4 & 150.1 & 4.7 & 325.0 & 2355 \\
\hline & & Fall & 2.2 & 0.48 & 2.2 & 102.7 & 4.9 & 324.1 & 2344 \\
\hline & & Winter & 3.8 & 0.50 & 0.1 & 3.6 & 5.2 & 177.6 & 2363 \\
\hline & & Annual & 2.5 & 0.43 & 1.7 & 67.0 & 5.0 & 266.3 & 9461 \\
\hline & CN-API & Annual & 50.8 & 0.33 & -18.4 & -36.3 & 28.4 & 42.2 & 42 \\
\hline \multirow{8}{*}{$\mathrm{NO}_{2}$} & US-AQS & Annual & 29.0 & 0.2 & -13.9 & -47.9 & 22.6 & 63.4 & 1616 \\
\hline & EU- AIRBASE & Annual & 32.0 & 0.4 & -17.1 & -53.5 & 22.5 & 55.9 & 747 \\
\hline & \multirow{5}{*}{ EU-EMEP } & Spring & 6.5 & 0.65 & -0.1 & -1.6 & 5.6 & 79.5 & 2049 \\
\hline & & Summer & 5.0 & 0.56 & -0.7 & -14.1 & 4.7 & 73.8 & 2066 \\
\hline & & Fall & 7.1 & 0.67 & 1.0 & 14.4 & 7.0 & 84.1 & 2084 \\
\hline & & Winter & 9.7 & 0.68 & 1.3 & 13.9 & 7.9 & 91.6 & 2068 \\
\hline & & Annual & 7.1 & 0.68 & 0.4 & 5.6 & 6.4 & 82.3 & 8267 \\
\hline & CN-API & Annual & 46.6 & 0.08 & -31.5 & -67.5 & 36.1 & 66.2 & 42 \\
\hline \multirow{13}{*}{$\mathrm{O}_{3} *$} & \multirow[t]{4}{*}{ US-CASTNET } & Spring & 168.1 & 0.52 & -22.8 & -13.6 & 29.7 & 16.1 & 1269 \\
\hline & & Summer & 176.8 & 0.59 & -14.3 & -8.1 & 30.5 & 14.5 & 1512 \\
\hline & & Fall & 155.3 & 0.60 & -3.9 & -2.5 & 23.5 & 12.4 & 1071 \\
\hline & & Winter & 112.5 & 0.51 & -3.6 & -3.2 & 10.1 & 7.6 & 217 \\
\hline & EU-AIRBASE & Annual & 169.4 & 0.40 & 14.4 & 8.5 & 38.9 & 17.4 & 2776 \\
\hline & \multirow[t]{4}{*}{ EU-EMEP } & Spring & 140.9 & 0.56 & -2.1 & -1.5 & 22.7 & 14.2 & 4145 \\
\hline & & Summer & 152.3 & 0.60 & 6.5 & 4.3 & 30.5 & 18.4 & 4161 \\
\hline & & Fall & 108.5 & 0.66 & 18.4 & 16.9 & 25.4 & 25.9 & 4151 \\
\hline & & Winter & 92.5 & 0.29 & 3.1 & 3.4 & 16.1 & 16.6 & 4111 \\
\hline & \multirow[t]{4}{*}{ WDCGG-JP } & Spring & 165.4 & 0.68 & -8.9 & -5.4 & 26.1 & 14.4 & 175 \\
\hline & & Summer & 157.3 & 0.83 & 10.8 & 6.9 & 34.0 & 21.4 & 172 \\
\hline & & Fall & 128.5 & 0.62 & 17.4 & 13.5 & 31.4 & 21.9 & 173 \\
\hline & & Winter & 109.2 & 0.49 & 3.2 & 2.9 & 15.1 & 12.6 & 172 \\
\hline
\end{tabular}

also contribute to such bias characteristics. Slightly better performance is noted for $\mathrm{NO}_{3}^{-}$at EU-EMEP sites, with a higher $R(>0.6)$ and smaller bias (NMB: -67 to $23 \%$ ) for all seasons.

Performance for the $\mathrm{NH}_{4}^{+}$simulation is better than that of $\mathrm{NO}_{3}^{-}$but slightly worse than for $\mathrm{SO}_{4}^{2-}$. The NMB for USCASTNET is -54 to $23 \%$ which is comparable with Wang et al. (2009) $(|\mathrm{NMB}|<50 \%)$. Similar performance statistics are shown for EU-EMEP (NMB: -15 to $68 \%$ ).

\subsubsection{Elemental carbon (EC) concentration}

As elemental carbon (EC) is a primary pollutant, its spatial distributions exhibit a strong correlation to its emissions. The correlation between the observed and simulated EC concentrations is high, with $R>0.5$, though the model significantly underestimates the concentrations. NMB is up to $-74 \%$, which is worse than previous modeling studies utilizing relatively higher spatial resolution (Zhang et al., 2009; NMB $=-15.4$ to $8 \%$; Eder and Yu, 2006; $\mathrm{NMB}=-6 \%$ ), but the 
Table 2b. Model performance. Fine particles.

\begin{tabular}{|c|c|c|c|c|c|c|c|c|c|}
\hline Species & Network & & $\begin{array}{r}\text { Obs } \\
\left(\mu \mathrm{g} \mathrm{m}^{-3}\right)\end{array}$ & $R$ & $\begin{array}{r}\mathrm{MB} \\
\left(\mu \mathrm{g} \mathrm{m}^{-3}\right)\end{array}$ & $\begin{array}{r}\mathrm{NMB} \\
(\%)\end{array}$ & $\begin{array}{r}\text { RMSE } \\
\left(\mu \mathrm{g} \mathrm{m}^{-3}\right)\end{array}$ & $\begin{array}{r}\mathrm{NME} \\
(\%)\end{array}$ & $\begin{array}{r}N \\
\text { pairs }\end{array}$ \\
\hline \multirow{15}{*}{$\mathrm{SO}_{4}^{2-}$} & \multirow[t]{5}{*}{ US-CASTNET } & Spring & 3.1 & 0.87 & -0.2 & -7.5 & 0.8 & 29.2 & 2316 \\
\hline & & Summer & 5.3 & 0.86 & -2.4 & -45.2 & 3.1 & 44.7 & 2352 \\
\hline & & Fall & 3.7 & 0.86 & -1.0 & -26.5 & 1.8 & 34.3 & 2348 \\
\hline & & Winter & 2.3 & 0.63 & -0.8 & -35.6 & 1.2 & 53.1 & 2316 \\
\hline & & Annual & 3.6 & 0.81 & -1.1 & -30.8 & 1.9 & 40.3 & 9332 \\
\hline & \multirow[t]{5}{*}{ US-IMPROVE } & Spring & 1.4 & 0.89 & 0.3 & 22.5 & 0.7 & 70.3 & 1602 \\
\hline & & Summer & 2.2 & 0.90 & -0.6 & -28.9 & 1.8 & 37.8 & 1596 \\
\hline & & Fall & 1.3 & 0.90 & 0.2 & 15.7 & 0.7 & 68.4 & 1605 \\
\hline & & Winter & 0.9 & 0.76 & 0.1 & 16.3 & 0.6 & 106.7 & 1605 \\
\hline & & Annual & 1.4 & 0.85 & 0.0 & 0.7 & 1.1 & 70.8 & 6408 \\
\hline & \multirow[t]{5}{*}{ EU-EMEP } & Spring & 2.6 & 0.68 & 0.3 & 12.5 & 1.4 & 52.3 & 2099 \\
\hline & & Summer & 2.4 & 0.68 & 0.1 & 3.7 & 1.3 & 41.4 & 2071 \\
\hline & & Fall & 2.2 & 0.64 & 0.0 & 1.9 & 1.4 & 55.9 & 2042 \\
\hline & & Winter & 2.4 & 0.53 & -0.7 & -28.6 & 1.9 & 58.3 & 2058 \\
\hline & & Annual & 2.4 & 0.61 & -0.1 & -2.4 & 1.5 & 51.9 & 8270 \\
\hline \multirow{15}{*}{$\mathrm{NO}_{3}^{-}$} & \multirow[t]{5}{*}{ US-CASTNET } & Spring & 1.1 & 0.69 & 1.0 & 92.9 & 2.1 & 195.5 & 2316 \\
\hline & & Summer & 0.4 & 0.31 & -0.2 & -48.2 & 0.4 & 76.1 & 2352 \\
\hline & & Fall & 0.7 & 0.68 & 0.1 & 13.8 & 0.7 & 99.3 & 2348 \\
\hline & & Winter & 1.6 & 0.71 & 1.2 & 75.2 & 1.9 & 262.0 & 2316 \\
\hline & & Annual & 0.9 & 0.72 & 0.5 & 56.4 & 1.5 & 157.7 & 9332 \\
\hline & \multirow[t]{5}{*}{ US-IMPROVE } & Spring & 0.4 & 0.72 & 0.4 & 106.9 & 1.0 & 164.8 & 1602 \\
\hline & & Summer & 0.2 & 0.10 & -0.1 & -40.5 & 0.2 & 93.0 & 1596 \\
\hline & & Fall & 0.3 & 0.66 & 0.0 & 11.4 & 0.4 & 125.7 & 1604 \\
\hline & & Winter & 0.5 & 0.66 & 0.5 & 94.8 & 1.1 & 226.9 & 1605 \\
\hline & & Annual & 0.3 & 0.66 & 0.2 & 59.1 & 0.8 & 152.7 & 6407 \\
\hline & \multirow[t]{5}{*}{ EU-EMEP } & Spring & 3.0 & 0.75 & 0.3 & 10.8 & 2.0 & 75.2 & 679 \\
\hline & & Summer & 1.8 & 0.74 & -1.2 & -67.0 & 1.5 & 74.7 & 656 \\
\hline & & Fall & 2.3 & 0.72 & -0.4 & -15.0 & 1.5 & 64.4 & 659 \\
\hline & & Winter & 2.6 & 0.64 & 0.6 & 23.1 & 2.1 & 91.2 & 671 \\
\hline & & Annual & 2.4 & 0.70 & -0.2 & -6.3 & 1.8 & 76.4 & 2665 \\
\hline \multirow{10}{*}{$\mathrm{NH}_{4}^{+}$} & \multirow[t]{5}{*}{ US-CASTNET } & Spring & 1.2 & 0.68 & 0.3 & 22.6 & 0.8 & 52.0 & 2316 \\
\hline & & Summer & 1.6 & 0.77 & -0.8 & -53.7 & 1.1 & 50.5 & 2352 \\
\hline & & Fall & 1.2 & 0.72 & -0.3 & -21.4 & 0.6 & 31.7 & 2348 \\
\hline & & Winter & 1.1 & 0.76 & 0.2 & 19.0 & 0.6 & 54.1 & 2316 \\
\hline & & Annual & 1.3 & 0.52 & -0.2 & -12.9 & 0.8 & 47.0 & 9332 \\
\hline & \multirow{5}{*}{ EU-EMEP } & Spring & 1.4 & 0.69 & 0.7 & 51.3 & 1.4 & 101.4 & 335 \\
\hline & & Summer & 1.2 & 0.64 & -0.2 & -15.2 & 0.9 & 43.9 & 330 \\
\hline & & Fall & 1.2 & 0.67 & 0.3 & 28.2 & 1.0 & 73.7 & 332 \\
\hline & & Winter & 1.1 & 0.62 & 0.8 & 68.4 & 1.4 & 110.4 & 328 \\
\hline & & Annual & 1.2 & 0.62 & 0.4 & 33.7 & 1.2 & 82.4 & 1325 \\
\hline \multirow{5}{*}{$\mathrm{EC}$} & \multirow[t]{5}{*}{ US-IMPROVE } & Spring & 0.2 & 0.79 & -0.1 & -62.5 & 0.2 & 62.7 & 1536 \\
\hline & & Summer & 0.3 & 0.54 & -0.2 & -73.5 & 0.3 & 92.7 & 1532 \\
\hline & & Fall & 0.3 & 0.81 & -0.2 & -64.4 & 0.3 & 65.9 & 1548 \\
\hline & & Winter & 0.2 & 0.85 & -0.1 & -59.4 & 0.2 & 55.7 & 1542 \\
\hline & & Annual & 0.2 & 0.74 & -0.2 & -65.1 & 0.3 & 69.2 & 6158 \\
\hline
\end{tabular}


magnitude of NMB is comparable with Wang et al. (2009) $(\mathrm{NMB}=101.7 \%)$, which also utilized coarse spatial resolution. Some previous CMAQ modeling studies (Tesche et al., 2006; Appel et al., 2008) with higher spatial resolution also found a similar underestimation of EC, indicating other factors besides model resolution, such as uncertainties of PM speciation profiles used to estimate the EC emissions, might also contribute to such low biases.

\subsection{Trend analysis}

Simulated trends in $\mathrm{SO}_{2}, \mathrm{NO}_{2}, \mathrm{O}_{3}, \mathrm{SO}_{4}^{2-}, \mathrm{NO}_{3}^{-}, \mathrm{NH}_{4}^{+}$and $\mathrm{EC}$ concentrations in three regions (eastern China, eastern US and Europe) are given in Table 3. To help understand the changes, trends in input emissions used in this study are also provided in Table 3 as well as depicted in Fig. 2. Capability of the CMAQ model to capture the observed trends was examined through comparisons with network measurements, and both simulated and observed trends are quantified in Table 4 and Figs. 3-9.

\subsection{1 $\mathrm{SO}_{2}$ and $\mathrm{NO}_{2}$ trends}

Simulated trends in both $\mathrm{SO}_{2}$ and $\mathrm{NO}_{2}$ concentrations over the Northern Hemisphere reflect trends in $\mathrm{SO}_{2}$ and $\mathrm{NO}_{\mathrm{x}}$ emissions, respectively (see Figs. 2a-b, 3a and 4a), with a pronounced increasing trend in Asia and decreasing trend in Europe and North America. In particular, in China, annual change rates of $\mathrm{SO}_{2}$ and $\mathrm{NO}_{2}$ concentration are about 2.7 and $4.1 \%$, which are comparable to their corresponding emission rates $\left(\mathrm{SO}_{2}\right.$ and $\left.\mathrm{NO}_{\mathrm{x}}\right)$ of 3.2 and $4.3 \%$, respectively. Annual change rates of $\mathrm{SO}_{2}$ and $\mathrm{NO}_{2}$ concentrations in the US $(-5.7 \%$ and $-1.4 \%)$ and Europe $(-5.1 \%$ and $-1.2 \%)$ are also close to the rates of emission changes in both regions, at $-5.4 \%$ and $-1.8 \%$, and $-5.4 \%$ and $-1.5 \%$, respectively.

Such decreasing trends in the US and Europe are comparable with those inferred from observations at the different networks. The annual change rates of $\mathrm{SO}_{2}$ observed from US-CASTNET and US-AQS are -5.0 and $-5.3 \%$, close to that simulated by the model as -6.6 and $-6.5 \%$. Most of the reductions are located in the eastern US as seen in Fig. 3e-f. The model was unable to capture the increasing trend at two of the eastern AQS sites and also the large decreasing trend at a few sites in the Midwest. It should be noted that the $\mathrm{AQS} \mathrm{SO}_{2}$ measurements predominantly represent urban conditions, and the ability of a coarse resolution model to capture $\mathrm{SO}_{2}$ levels and trends is influenced both by its inability to accurately represent sub-grid variability as well as changes in local emissions. For instance, the monitor in Kansas City, $\mathrm{MO}$, shows a sharp increase in $\mathrm{SO}_{2}$ levels starting 2003; in contrast the grid-averaged $\mathrm{SO}_{2}$ emissions in the corresponding model cell show systematic decreasing trends over the 21-year period resulting in the simulated decreasing $\mathrm{SO}_{2}$ trend at this location. Also, as seen in the scatter plots in these panels, the pathway of such reductions from 1990 to 2010 is in good agreement between observation and simulation. Stronger trends are noted in winter when $\mathrm{SO}_{2}$ concentrations are higher compared to other seasons in both observed $\left(-0.368 \mu \mathrm{g} \mathrm{m}^{-3} \mathrm{yr}^{-1}\right)$ and simulated trends $\left(-0.366 \mu \mathrm{g} \mathrm{m}^{-3} \mathrm{yr}^{-1}\right)$ at US-CASTNET (see Table 4). Annual change rates of $\mathrm{SO}_{2}$ observed from EU-AIRBASE and EU-EMEP are -8.9 and $-7.3 \%$, which are close to that simulated by the model at -5.9 and $-6.1 \%$, with higher rates in winter when $\mathrm{SO}_{2}$ concentration are at their highest level. Significant reductions are found at locations in the southern UK, the Benelux countries, Germany, Italy, Czech Republic, Poland, Hungary and Romania.

The overall reductions in $\mathrm{NO}_{2}$ from 1990 to 2010 are also in good agreement between the observations and model simulations. Observed decreasing trends of $\mathrm{NO}_{2}$ concentrations (and annual change rate) are shown in urban networks, i.e., US-AQS and EU-AIRBASE are $-0.63 \mu \mathrm{g} \mathrm{m}^{-3} \mathrm{yr}^{-1}$ $(-2.3 \%)$ and $-0.64 \mu \mathrm{g} \mathrm{m}^{-3} \mathrm{yr}^{-1}(-1.9 \%)$, respectively. Model-simulated trends (and annual change rate) at these two urban network, $-0.32 \mu \mathrm{g} \mathrm{m}^{-3} \mathrm{yr}^{-1}(-2.2 \%)$ and $-0.14 \mu \mathrm{g} \mathrm{m}^{-3} \mathrm{yr}^{-1}(-0.9 \%)$, respectively, are however underestimated. The reason might be associated with the underestimation of $\mathrm{NO}_{2}$ concentrations. The model slightly overestimated the trends (annual change rates as well) at the rural EU-EMEP network $\left(-0.16 \mu \mathrm{g} \mathrm{m}^{-3} \mathrm{yr}^{-1}(-2.0 \%)\right.$ from the model, compared to the observed trends of $\left.-0.13 \mu \mathrm{g} \mathrm{m}^{-3} \mathrm{yr}^{-1}(-1.7 \%)\right)$. Such decreasing trends are more pronounced over the eastern US, California, the southern UK, northern France, the Benelux countries and Germany.

Large increases in the remotely sensed $\mathrm{NO}_{2}$ vertical column density (VCD) over eastern China over the past decade have been noted in many studies (Richter et al., 2005; Irie et al., 2005; Akimoto et al., 2006; Zhang et al., 2007) but very limited in situ data are available. Trends in $\mathrm{SO}_{2}$ and $\mathrm{NO}_{2}$ inferred from available CN-API data (for 6 years) were not significant (Table 4 and Fig. 3-4b); the model was unable to capture these trends, yielding trends more similar to those of the emissions. These discrepancies could likely arise from uncertainties in local emissions as well as the coarse spatial resolution which limits the model's ability to represent pollution distribution at a finer scale which is likely captured at these monitors. Some industries were moved out of city centers to rural areas nearby so that the improvement of local air quality observed in city centers cannot be captured by large-scale simulations. However, the model results agree with the findings from studies analyzing satellite information over Asia. For example, Zhang et al. (2012) analyzed SCIAMACHY-SO ${ }_{2}$ VCD during 2004-2009, suggesting a continuous increase in tropospheric $\mathrm{SO}_{2}$ loading in western China, but transition from increase to decrease in 2007 in eastern China resulting from stricter controls. 
Table 3. Simulated trends in three regions (grid-averaged).

\begin{tabular}{|c|c|c|c|c|c|c|}
\hline \multirow[b]{2}{*}{ Emission } & \multicolumn{2}{|c|}{ Eastern China } & \multicolumn{2}{|c|}{ Eastern US } & \multicolumn{2}{|c|}{ Europe } \\
\hline & $\mathrm{kg} \mathrm{km}^{-2} \mathrm{yr}^{-1}$ & $\% \mathrm{yr}^{-1}$ & $\mathrm{~kg} \mathrm{~km}^{-2} \mathrm{yr}^{-1}$ & $\% \mathrm{yr}^{-1}$ & $\mathrm{~kg} \mathrm{~km}^{-2} \mathrm{yr}^{-1}$ & $\% \mathrm{yr}^{-1}$ \\
\hline $\mathrm{SO}_{2}$ & 20.2 & 3.2 & -16.1 & -5.4 & -20.4 & -5.4 \\
\hline $\mathrm{NO}_{\mathrm{x}}$ & 8.5 & 4.3 & -3.7 & -1.8 & -3.0 & -1.5 \\
\hline VOC & 18.6 & 2.3 & -22.5 & -3.3 & -26.7 & -3.3 \\
\hline $\mathrm{NH}_{3}$ & 6.5 & 2.6 & 1.7 & 1.6 & -2.6 & -1.0 \\
\hline $\mathrm{PM}_{10}$ & 2.1 & 0.3 & -4.5 & -4.6 & -10.0 & -4.8 \\
\hline Concentration & $\mu \mathrm{g} \mathrm{m}^{-3} \mathrm{yr}^{-1}$ & $\% \mathrm{yr}^{-1}$ & $\mu \mathrm{g} \mathrm{m}^{-3} \mathrm{yr}^{-1}$ & $\% \mathrm{yr}^{-1}$ & $\mu \mathrm{g} \mathrm{m}^{-3} \mathrm{yr}^{-1}$ & $\% \mathrm{yr}^{-1}$ \\
\hline $\mathrm{SO}_{2}$ & 0.265 & 2.70 & -0.175 & -5.71 & -0.178 & -5.06 \\
\hline $\mathrm{NO}_{2}$ & 0.119 & 4.14 & -0.048 & -1.38 & -0.040 & -1.16 \\
\hline $\mathrm{O}_{3} *$ & 2.566 & 1.49 & -1.028 & -0.66 & -0.875 & -0.54 \\
\hline $\mathrm{PM}_{2.5}$ & 0.481 & 2.21 & -0.097 & -1.21 & -0.253 & -2.62 \\
\hline $\mathrm{SO}_{4}^{2-}$ & 0.185 & 2.82 & -0.072 & -3.17 & -0.109 & -3.73 \\
\hline $\mathrm{NO}_{3}^{-}$ & 0.097 & 5.40 & 0.014 & 1.61 & -0.030 & -1.84 \\
\hline $\mathrm{NH}_{4}^{+}$ & 0.081 & 3.44 & -0.006 & -0.72 & -0.041 & -2.91 \\
\hline $\mathrm{EC}$ & 0.005 & 0.99 & -0.004 & -3.39 & -0.005 & -2.46 \\
\hline
\end{tabular}

Formatted entries are significant at $p=0.05$ level: italic $=$ significant decrease; bold $=$ significant increase. ${ }^{*}$ Trend in $\mathrm{O}_{3}$ is computed on the basis of annual or seasonal maximum of DM8 (daily $8 \mathrm{~h}$ maxima) value.

\subsection{2 $\mathrm{O}_{3}$ trends}

Ozone concentrations are sensitive to the control of $\mathrm{NO}_{\mathrm{x}}$ and VOC emissions and studies have indicated that the control in $\mathrm{NO}_{\mathrm{x}}$ emissions without a simultaneous significant reduction of VOC might lead to an increase of daily $\mathrm{O}_{3}$ due to the switch from a VOC-limited to $\mathrm{NO}_{\mathrm{x}}$-limited regime (e.g., Chameides et al., 1992; Sillman, 1999). However, $\mathrm{O}_{3}$ chemistry is likely to occur at $\mathrm{NO}_{\mathrm{x}}$-limited regimes during periods of heavy photochemical pollution (Trainer et al., 1993; Xing et al., 2011b), suggesting that $\mathrm{NO}_{\mathrm{x}}$ controls are more effective in reducing annual maxima (rather than averages) of $\mathrm{DM} 8 \mathrm{O}_{3}$. Therefore, trends in $\mathrm{NO}_{\mathrm{x}}$ emission are more likely to have positive correlations with trends in annual maxima (rather than averages) of DM8 $\mathrm{O}_{3}$. As expected, the simulated trends of annual maxima of DM8 $\mathrm{O}_{3}$ concentration (see Fig. 5a) look quite similar to the $\mathrm{NO}_{\mathrm{x}}$ and VOC emission trends (Fig. $2 \mathrm{~b}-\mathrm{c}$ ). The simulated increasing rate of annual maxima of DM8 $\mathrm{O}_{3}$ in eastern China is $1.49 \%$, which is associated with the increase in $\mathrm{NO}_{\mathrm{x}}$ and $\mathrm{VOC}$ emissions (by 4.3 and $2.3 \%$ per year). In contrast, due to reductions of emissions, substantial decreasing trends in annual maxima of DM8 $\mathrm{O}_{3}$ are apparent in both the eastern US and Europe, with magnitudes of -0.66 and $-0.54 \%$ per year, respectively (see Table 3). Significant increases of $\mathrm{O}_{3}$ are also shown in northern India, western Asia and sub-Saharan Africa where both $\mathrm{NO}_{\mathrm{x}}$ and VOC emissions have increased during this period (see Fig. 2b-c).

Observed decreasing trends in annual maximum of DM8 $\mathrm{O}_{3}$ concentrations (and annual change rate) in EU-EMEP, EU-AIRBASE and US-CASTNET are $-1.07 \mu \mathrm{g} \mathrm{m}^{-3} \mathrm{yr}^{-1}(-0.7 \%),-1.35 \mu \mathrm{g} \mathrm{m}^{-3} \mathrm{yr}^{-1}(-0.8 \%)$ and $-1.86 \mu \mathrm{g} \mathrm{m}^{-3} \mathrm{yr}^{-1} \quad(-1.1 \%)$, respectively. Similar trends are estimated by the model simulation for both networks, i.e., $-1.31 \mathrm{\mu g} \mathrm{m}^{-3} \mathrm{yr}^{-1} \quad(-0.9 \%)$, $-2.13 \mu \mathrm{g} \mathrm{m}^{-3} \mathrm{yr}^{-1} \quad(-1.1 \%)$ and $-0.95 \mu \mathrm{g} \mathrm{m}^{-3} \mathrm{yr}^{-1}$ $(-0.6 \%)$ (see Table 4). The failure to capture the slightly increasing trends in observations in the urban network (i.e., EU-AIRBASE) might be associated with the limitation by coarse spatial resolution that causes the model to fail to represent the VOC-limited regime at these urban locations and a likely switch of $\mathrm{O}_{3}$ chemistry from a VOC- to $\mathrm{NO}_{\mathrm{x}}$-limited regime which usually goes along with the transition from urban to rural area (e.g., Xing et al., 2011b). Such decreasing trends are noted in all seasons except during winter, when $\mathrm{O}_{3}$ is at the lowest level. In contrast, the most significant reduction occurred in summer when $\mathrm{O}_{3}$ concentrations are at the highest. The spatial pattern of $\mathrm{O}_{3}$ trends is quite similar to that of $\mathrm{NO}_{2}$, with more pronounced decreases in regions downwind of urban areas across the eastern US and California as well as southern UK, northern France, the Benelux countries and Germany. The reason for increasing trends shown in both observations and the model in the Midwest US might be explained by the changes in local emissions (less or no controls in Midwest) as well as increasing long-range transport of pollutants across the Pacific (Mathur et al., 2014). Analysis of long-term observations at remote sites along the western US (e.g., Jaffe and Ray, 2007; Parrish et al., 2009) also show increasing trends in $\mathrm{O}_{3}$ within the boundary layer attributable to inflow from the Pacific.

Though long-term observation records of $\mathrm{O}_{3}$ are not available in China, recent studies have suggested increasing trends similar to those found here. For instance, Xu et al. (2011) suggested significant increasing trends in tropospheric ozone 
Table 4. Comparison of observed and simulated trends $\left(\mu \mathrm{g} \mathrm{m}^{-3} \mathrm{yr}^{-1}\right.$, computed on the basis of annual and seasonal means over the 19902010 period with a linear least square fit method) and the annual change rate ( $x \%$, i.e., concentration in the year $Y\left(C_{Y}\right)$ will be fit as $\left.C_{Y}=C_{1990} \times(1+x)^{Y-1990}\right)$.

\begin{tabular}{|c|c|c|c|c|c|c|c|c|c|c|c|c|}
\hline \multirow[t]{2}{*}{ Species } & \multirow[t]{2}{*}{ Network } & & \multicolumn{2}{|c|}{ Spring } & \multicolumn{2}{|c|}{ Summer } & \multicolumn{2}{|c|}{ Fall } & \multicolumn{2}{|c|}{ Winter } & \multicolumn{2}{|c|}{ Annual } \\
\hline & & & obs & $\operatorname{sim}$ & & $\operatorname{sim}$ & obs & $\operatorname{sim}$ & obs & $\operatorname{sim}$ & & $\operatorname{sim}$ \\
\hline \multirow{5}{*}{$\mathrm{SO}_{2}$} & US-CASTNET & $\begin{array}{l}\mu \mathrm{g} \mathrm{m}^{-3} \\
\%\end{array}$ & $\begin{array}{r}-0.228 \\
-4.74\end{array}$ & $\begin{array}{r}-0.238 \\
-6.26\end{array}$ & $\begin{array}{r}-0.152 \\
-4.91\end{array}$ & $\begin{array}{r}-0.204 \\
-6.13\end{array}$ & $\begin{array}{r}-0.234 \\
-5.61\end{array}$ & $\begin{array}{r}-0.385 \\
-6.63\end{array}$ & $\begin{array}{r}-0.368 \\
-4.79\end{array}$ & $\begin{array}{r}-0.366 \\
-7.01\end{array}$ & $\begin{array}{r}-0.245 \\
-4.98\end{array}$ & $\begin{array}{r}-0.298 \\
-6.57\end{array}$ \\
\hline & US-AQS & $\begin{array}{l}\mu \mathrm{g} \mathrm{m}^{-3} \\
\%\end{array}$ & & & & & & & & & $\begin{array}{r}-0.626 \\
-5.31\end{array}$ & $\begin{array}{r}-0.467 \\
-6.45\end{array}$ \\
\hline & EU-AIRBASE & $\begin{array}{l}\mu \mathrm{g} \mathrm{m}^{-3} \\
\%\end{array}$ & & & & & & & & & $\begin{array}{r}-0.873 \\
-8.86\end{array}$ & $\begin{array}{r}-0.441 \\
-5.86\end{array}$ \\
\hline & EU-EMEP & $\begin{array}{l}\mu \mathrm{g} \mathrm{m}^{-3} \\
\%\end{array}$ & $\begin{array}{r}-0.187 \\
-7.03\end{array}$ & $\begin{array}{r}-0.282 \\
-6.16\end{array}$ & $\begin{array}{r}-0.108 \\
-5.95\end{array}$ & $\begin{array}{r}-0.225 \\
-5.53\end{array}$ & $\begin{array}{r}-0.180 \\
-7.28\end{array}$ & $\begin{array}{r}-0.279 \\
-6.23\end{array}$ & $\begin{array}{r}-0.339 \\
-8.04\end{array}$ & $\begin{array}{r}-0.264 \\
-6.28\end{array}$ & $\begin{array}{r}-0.204 \\
-7.26\end{array}$ & $\begin{array}{r}-0.262 \\
-6.05\end{array}$ \\
\hline & CN-API & $\underset{\%}{\mu g^{-3}}$ & & & & & & & & & $\begin{array}{r}0.376 \\
0.66\end{array}$ & $\begin{array}{r}1.230 \\
4.02\end{array}$ \\
\hline \multirow{4}{*}{$\mathrm{NO}_{2}$} & US-AQS & $\begin{array}{l}\mu \mathrm{g} \mathrm{m}^{-3} \\
\%\end{array}$ & & & & & & & & & $\begin{array}{r}-0.629 \\
-2.3\end{array}$ & $\begin{array}{r}-0.311 \\
-2.2\end{array}$ \\
\hline & EU-AIRBASE & $\begin{array}{l}\mu \mathrm{g} \mathrm{m}^{-3} \\
\%\end{array}$ & & & & & & & & & $\begin{array}{r}-0.640 \\
-1.88\end{array}$ & $\begin{array}{r}-0.136 \\
-0.86\end{array}$ \\
\hline & EU-EMEP & $\begin{array}{l}\mu \mathrm{g} \mathrm{m}^{-3} \\
\%\end{array}$ & $\begin{array}{r}-0.087 \\
-1.29\end{array}$ & $\begin{array}{r}-0.113 \\
-1.64\end{array}$ & $\begin{array}{r}-0.115 \\
-2.26\end{array}$ & $\begin{array}{r}-0.137 \\
-3.03\end{array}$ & $\begin{array}{r}-0.150 \\
-2.00\end{array}$ & $\begin{array}{r}-0.194 \\
-2.30\end{array}$ & $\begin{array}{r}-0.150 \\
-1.46\end{array}$ & $\begin{array}{r}-0.195 \\
-1.70\end{array}$ & $\begin{array}{r}-0.126 \\
-1.69\end{array}$ & $\begin{array}{r}-0.160 \\
-2.04\end{array}$ \\
\hline & CN-API & $\begin{array}{l}\mu \mathrm{g} \mathrm{m}^{-3} \\
\%\end{array}$ & & & & & & & & & $\begin{array}{r}-0.454 \\
-0.97\end{array}$ & $\begin{array}{r}0.868 \\
5.94\end{array}$ \\
\hline \multirow{6}{*}{$\mathrm{O}_{3} *$} & US-CASTNET & $\begin{array}{l}\mu \mathrm{g} \mathrm{m}^{-3} \\
\%\end{array}$ & $\begin{array}{r}-1.187 \\
-0.73\end{array}$ & $\begin{array}{r}-0.903 \\
-0.65\end{array}$ & $\begin{array}{r}-1.860 \\
-1.14\end{array}$ & $\begin{array}{r}-1.010 \\
-0.68\end{array}$ & $\begin{array}{r}-1.220 \\
-0.83\end{array}$ & $\begin{array}{r}-0.527 \\
-0.36\end{array}$ & $\begin{array}{r}-0.029 \\
-0.02\end{array}$ & $\begin{array}{r}-0.134 \\
-0.13\end{array}$ & $\begin{array}{r}-1.859 \\
-1.10\end{array}$ & $\begin{array}{r}-0.952 \\
-0.64\end{array}$ \\
\hline & EU-AIRBASE & $\underset{\%}{\mu g^{-3}}$ & & & & & & & & & $\begin{array}{r}-1.348 \\
-0.79\end{array}$ & $\begin{array}{r}-2.129 \\
-1.13\end{array}$ \\
\hline & EU-EMEP & $\begin{array}{l}\mu \mathrm{g} \mathrm{m}^{-3} \\
\%\end{array}$ & $\begin{array}{r}-0.651 \\
-0.46\end{array}$ & $\begin{array}{r}-1.281 \\
-0.92\end{array}$ & $\begin{array}{r}-1.207 \\
-0.85\end{array}$ & $\begin{array}{r}-1.365 \\
-0.91\end{array}$ & $\begin{array}{r}-0.157 \\
-0.13\end{array}$ & $\begin{array}{r}-0.184 \\
-0.15\end{array}$ & $\begin{array}{r}0.124 \\
0.14\end{array}$ & $\begin{array}{r}-0.048 \\
-0.05\end{array}$ & $\begin{array}{r}-1.067 \\
-0.74\end{array}$ & $\begin{array}{r}-1.313 \\
-0.87\end{array}$ \\
\hline & WDCGG-Minamitorishima & $\begin{array}{l}\mu \mathrm{g} \mathrm{m}^{-3} \\
\%\end{array}$ & $\begin{array}{r}0.485 \\
0.35\end{array}$ & $\begin{array}{r}-0.029 \\
-0.02\end{array}$ & $\begin{array}{r}-1.131 \\
-1.19\end{array}$ & $\begin{array}{r}-0.083 \\
0.01\end{array}$ & $\begin{array}{r}-0.688 \\
-0.70\end{array}$ & $\begin{array}{r}0.090 \\
0.09\end{array}$ & $\begin{array}{r}-0.416 \\
-0.31\end{array}$ & $\begin{array}{r}0.413 \\
0.38\end{array}$ & $\begin{array}{r}0.232 \\
0.18\end{array}$ & $\begin{array}{r}-0.126 \\
-0.11\end{array}$ \\
\hline & WDCGG-Ryori & $\begin{array}{l}\mu \mathrm{g} \mathrm{m}^{-3} \\
\%\end{array}$ & $\begin{array}{r}1.305 \\
0.79\end{array}$ & $\begin{array}{r}0.372 \\
0.24\end{array}$ & $\begin{array}{r}0.549 \\
0.44\end{array}$ & $\begin{array}{r}0.259 \\
0.18\end{array}$ & $\begin{array}{r}-0.638 \\
-0.47\end{array}$ & $\begin{array}{r}0.308 \\
0.25\end{array}$ & $\begin{array}{r}0.166 \\
0.24\end{array}$ & $\begin{array}{r}0.217 \\
0.23\end{array}$ & $\begin{array}{r}0.702 \\
0.41\end{array}$ & $\begin{array}{r}0.440 \\
0.29\end{array}$ \\
\hline & WDCGG-Tsukuba & $\begin{array}{l}\mu \mathrm{g} \mathrm{m}^{-3} \\
\%\end{array}$ & $\begin{array}{r}-1.073 \\
-0.60\end{array}$ & $\begin{array}{r}-0.019 \\
-0.02\end{array}$ & $\begin{array}{r}-4.015 \\
-1.78\end{array}$ & $\begin{array}{r}-0.375 \\
-0.18\end{array}$ & $\begin{array}{r}0.581 \\
0.52\end{array}$ & $\begin{array}{r}-1.017 \\
-0.56\end{array}$ & $\begin{array}{r}-0.368 \\
-0.31\end{array}$ & $\begin{array}{r}0.861 \\
0.74\end{array}$ & $\begin{array}{r}-3.299 \\
-1.40\end{array}$ & $\begin{array}{r}-0.022 \\
-0.01\end{array}$ \\
\hline \multirow{3}{*}{$\mathrm{SO}_{4}^{2-}$} & US-CASTNET & $\begin{array}{l}\mu \mathrm{g} \mathrm{m}^{-3} \\
\%\end{array}$ & $\begin{array}{r}-0.070 \\
-2.30\end{array}$ & $\begin{array}{r}-0.073 \\
-2.49\end{array}$ & $\begin{array}{r}-0.161 \\
-3.25\end{array}$ & $\begin{array}{r}-0.125 \\
-4.45\end{array}$ & $\begin{array}{r}-0.112 \\
-3.31\end{array}$ & $\begin{array}{r}-0.098 \\
-3.75\end{array}$ & $\begin{array}{r}-0.054 \\
-2.25\end{array}$ & $\begin{array}{r}-0.046 \\
-3.01\end{array}$ & $\begin{array}{r}-0.099 \\
-2.87\end{array}$ & $\begin{array}{r}-0.086 \\
-3.46\end{array}$ \\
\hline & US-IMPROVE & $\begin{array}{l}\mu \mathrm{g} \mathrm{m}^{-3} \\
\%\end{array}$ & $\begin{array}{r}-0.023 \\
-1.76\end{array}$ & $\begin{array}{r}-0.021 \\
-1.24\end{array}$ & $\begin{array}{r}-0.049 \\
-2.45\end{array}$ & $\begin{array}{r}-0.043 \\
-2.86\end{array}$ & $\begin{array}{r}-0.036 \\
-2.87\end{array}$ & $\begin{array}{r}-0.041 \\
-2.69\end{array}$ & $\begin{array}{r}-0.024 \\
-2.76\end{array}$ & $\begin{array}{r}-0.016 \\
-1.59\end{array}$ & $\begin{array}{r}-0.033 \\
-2.43\end{array}$ & $\begin{array}{r}-0.030 \\
-2.11\end{array}$ \\
\hline & EU-EMEP & $\underset{\%}{\mu g^{-3}}$ & $\begin{array}{r}-0.119 \\
-4.28\end{array}$ & $\begin{array}{r}-0.086 \\
-2.84\end{array}$ & $\begin{array}{r}-0.111 \\
-4.35\end{array}$ & $\begin{array}{r}-0.112 \\
-4.49\end{array}$ & $\begin{array}{r}-0.097 \\
-4.27\end{array}$ & $\begin{array}{r}-0.085 \\
-3.93\end{array}$ & $\begin{array}{r}-0.090 \\
-3.39\end{array}$ & $\begin{array}{r}-0.060 \\
-3.29\end{array}$ & $\begin{array}{r}-0.104 \\
-4.06\end{array}$ & $\begin{array}{r}-0.086 \\
-3.62\end{array}$ \\
\hline \multirow{3}{*}{$\mathrm{NO}_{3}^{-}$} & US-CASTNET & $\begin{array}{l}\mu \mathrm{g} \mathrm{m}^{-3} \\
\%\end{array}$ & $\begin{array}{r}-0.009 \\
-0.94\end{array}$ & $\begin{array}{r}0.023 \\
1.19\end{array}$ & $\begin{array}{r}-0.011 \\
-3.17\end{array}$ & $\begin{array}{r}0.005 \\
3.38\end{array}$ & $\begin{array}{r}-0.015 \\
-2.27\end{array}$ & $\begin{array}{r}0.023 \\
3.33\end{array}$ & $\begin{array}{r}0.009 \\
0.61\end{array}$ & $\begin{array}{r}0.057 \\
2.35\end{array}$ & $\begin{array}{r}-0.006 \\
-0.73\end{array}$ & $\begin{array}{r}0.027 \\
2.10\end{array}$ \\
\hline & US-IMPROVE & $\begin{array}{l}\mu \mathrm{g} \mathrm{m}^{-3} \\
\%\end{array}$ & $\begin{array}{r}-0.002 \\
-0.70\end{array}$ & $\begin{array}{r}0.012 \\
1.93\end{array}$ & $\begin{array}{r}-0.004 \\
-2.13\end{array}$ & $\begin{array}{r}0.000 \\
0.14\end{array}$ & $\begin{array}{r}-0.005 \\
-1.97\end{array}$ & $\begin{array}{r}0.010 \\
3.73\end{array}$ & $\begin{array}{r}-0.002 \\
-0.28\end{array}$ & $\begin{array}{r}0.024 \\
2.99\end{array}$ & $\begin{array}{r}-0.003 \\
-1.04\end{array}$ & $\begin{array}{r}0.012 \\
2.53\end{array}$ \\
\hline & EU-EMEP & $\begin{array}{l}\mu \mathrm{g} \mathrm{m}^{-3} \\
\%\end{array}$ & $\begin{array}{r}-0.015 \\
-0.47\end{array}$ & $\begin{array}{r}-0.086 \\
-2.49\end{array}$ & $\begin{array}{r}-0.019 \\
-1.06\end{array}$ & $\begin{array}{r}-0.032 \\
-5.38\end{array}$ & $\begin{array}{r}-0.009 \\
-0.51\end{array}$ & $\begin{array}{r}-0.043 \\
-2.19\end{array}$ & $\begin{array}{r}0.013 \\
0.50\end{array}$ & $\begin{array}{r}-0.002 \\
-0.13\end{array}$ & $\begin{array}{r}-0.008 \\
-0.33\end{array}$ & $\begin{array}{r}-0.041 \\
-1.74\end{array}$ \\
\hline \multirow{2}{*}{$\mathrm{NH}_{4}^{+}$} & US-CASTNET & $\begin{array}{l}\mu \mathrm{g} \mathrm{m}^{-3} \\
\%\end{array}$ & $\begin{array}{r}-0.023 \\
-2.04\end{array}$ & $\begin{array}{r}-0.002 \\
-0.19\end{array}$ & $\begin{array}{r}-0.038 \\
-2.60\end{array}$ & $\begin{array}{r}-0.010 \\
-1.54\end{array}$ & $\begin{array}{r}-0.032 \\
-2.86\end{array}$ & $\begin{array}{r}-0.006 \\
-0.68\end{array}$ & $\begin{array}{r}-0.013 \\
-1.24\end{array}$ & $\begin{array}{r}0.012 \\
0.97\end{array}$ & $\begin{array}{r}-0.026 \\
-2.19\end{array}$ & $\begin{array}{r}-0.002 \\
-0.18\end{array}$ \\
\hline & EU-EMEP & $\begin{array}{l}\mu \mathrm{g} \mathrm{m}^{-3} \\
\%\end{array}$ & $\begin{array}{r}0.003 \\
0.80\end{array}$ & $\begin{array}{r}-0.055 \\
-2.22\end{array}$ & $\begin{array}{r}0.000 \\
0.30\end{array}$ & $\begin{array}{r}-0.049 \\
-4.52\end{array}$ & $\begin{array}{r}0.020 \\
1.75\end{array}$ & $\begin{array}{r}-0.035 \\
-2.21\end{array}$ & $\begin{array}{r}-0.002 \\
0.16\end{array}$ & $\begin{array}{r}-0.018 \\
-0.87\end{array}$ & $\begin{array}{r}0.005 \\
0.70\end{array}$ & $\begin{array}{r}-0.039 \\
-2.19\end{array}$ \\
\hline EC & US-IMPROVE & $\begin{array}{l}\mu \mathrm{g} \mathrm{m}^{-3} \\
\%\end{array}$ & $\begin{array}{r}-0.005 \\
-2.46\end{array}$ & $\begin{array}{r}-0.002 \\
-2.77\end{array}$ & $\begin{array}{r}-0.003 \\
-1.34\end{array}$ & $\begin{array}{r}-0.002 \\
-3.42\end{array}$ & $\begin{array}{r}-0.009 \\
-3.30\end{array}$ & $\begin{array}{r}-0.004 \\
-3.67\end{array}$ & $\begin{array}{r}-0.008 \\
-3.41\end{array}$ & $\begin{array}{r}-0.003 \\
-3.32\end{array}$ & $\begin{array}{r}-0.006 \\
-2.64\end{array}$ & $\begin{array}{r}-0.003 \\
-3.32\end{array}$ \\
\hline
\end{tabular}
values, except that for AIRBASE which is computed on the basis of annual maximum of DM1 (daily $1 \mathrm{~h}$ maxima). 
(a) WRF-CMAQ Simulation

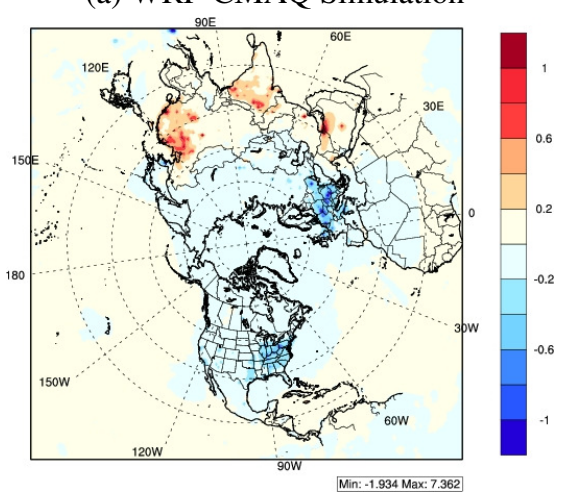

(b) China-API (2005-2010)
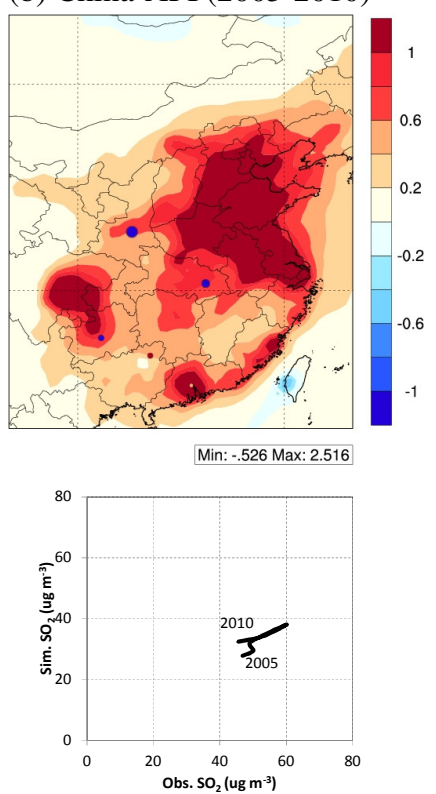

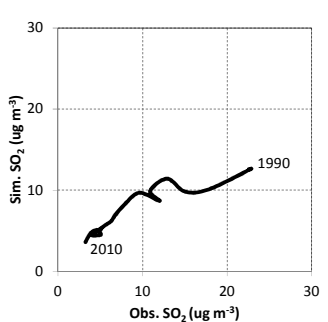

(c) AIRBASE

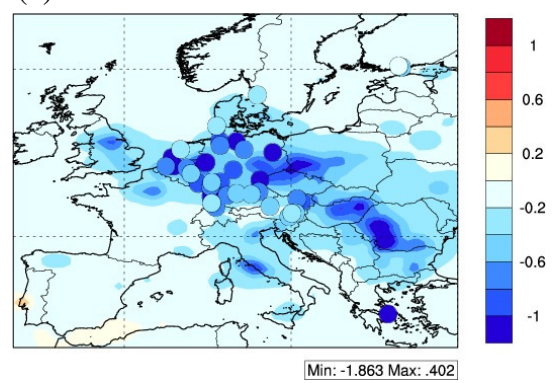

(d) EMEP

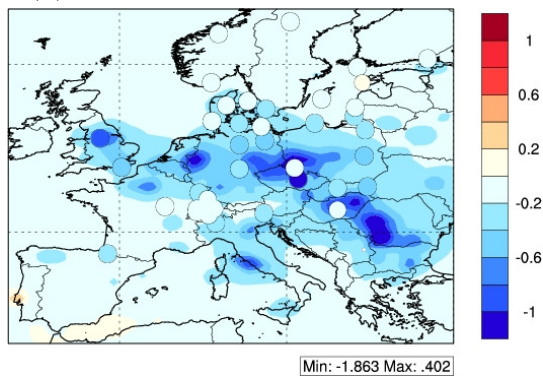

(e) AQS
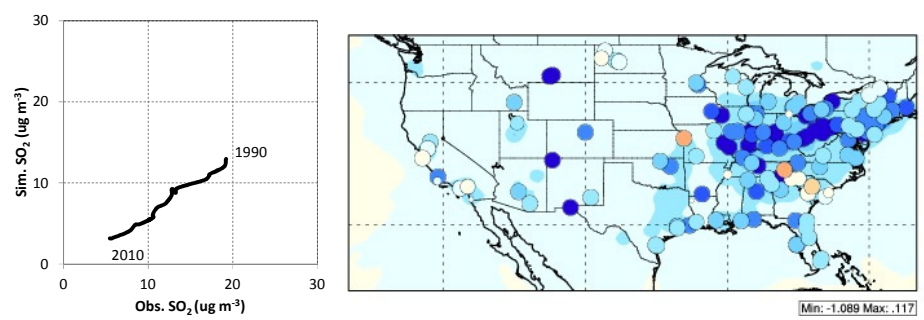

(f) CASTNET
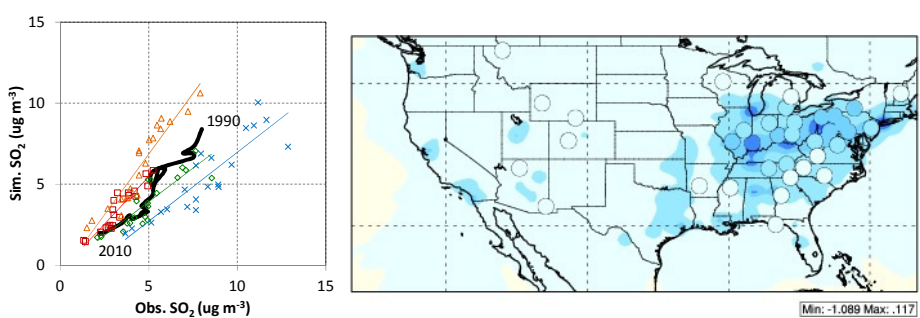
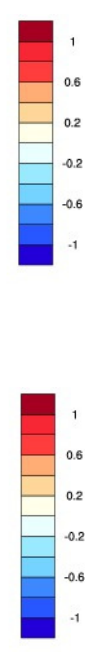

Figure 3. (a) simulated $\mathrm{SO}_{2}$ trend from WRF-CMAQ $\left(\mu \mathrm{g} \mathrm{m}^{-3} \mathrm{yr}^{-1}\right)$; (b) map: simulated $\mathrm{SO}_{2}$ trend in eastern China overlaid with observed $\mathrm{SO}_{2}$ trends from China-API, dots represent each observation site, computed on the basis of annual means over the 2005-2010 period with a linear least square fit method, dot size is determined by the significance of the trend, i.e., larger symbols denote more significant trends at the $p=0.05$ level $\left(\mu \mathrm{g} \mathrm{m}^{-3} \mathrm{yr}^{-1}\right)$; scatterplot: observed and simulated $\mathrm{SO}_{2}$ concentration, network mean for each year's corresponding grid cells from the model simulation are selected for comparison $\left(\mu \mathrm{g} \mathrm{m}^{-3}\right)$; (c) same as (b) for EU-AIRBASE; (d) same as (b) for EU-EMEP; (e) same as (b) for the US-AQS; (f) same as (b) for the US-CASTNET.

residual over the North China Plain. Ding et al. (2008) suggest that $\mathrm{O}_{3}$ in the lower troposphere over Beijing had a strong positive trend ( $2 \%$ per year) during the period 1995 to 2005 . Ozonesonde measurements analyzed by Wang et al. (2012) suggests a clear positive trend in the maximum summer ozone concentration (3.4\% per year) over the Beijing area during 2002-2010. In this study, the trend in summer maximum of DM8 ozone concentration in Beijing dur- ing 1990-2010 is estimated to be $2 \%$ per year, which is comparable to that inferred from observations in these two recent studies.

Observation records at three sites in WDCGG network were used to investigate trends in $\mathrm{O}_{3}$ distribution in eastern Asia. One of these sites, Minamitorishima (noted as S1, $24.28^{\circ} \mathrm{N}, 153.98^{\circ} \mathrm{E}$ ), is located far from land and can be considered to be a representative of clean conditions, while 
(a) WRF-CMAQ Simulation

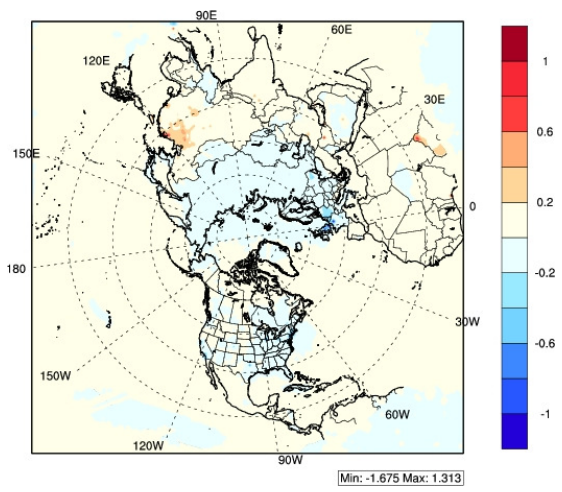

(b) China-API (2005-2010)

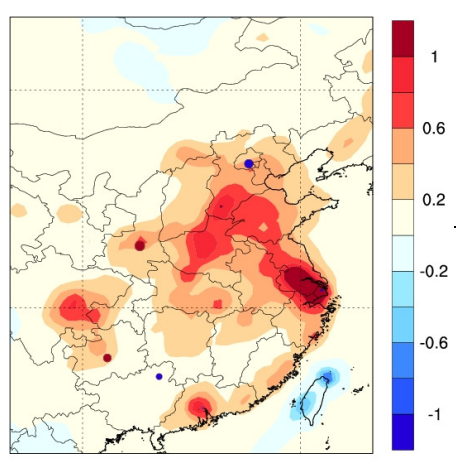

Min: -.811 Max: 1.98

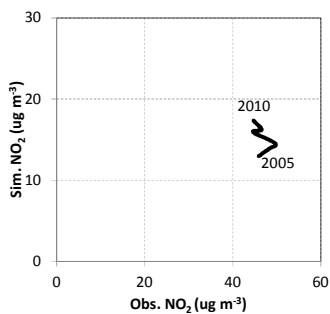

Figure 4. Same as Fig. 3 for $\mathrm{NO}_{2}$.

two sites located on Honshu, i.e., Tsukuba (noted as S2: $36.05^{\circ} \mathrm{N}, 140.13^{\circ} \mathrm{E}$ ) which is to the northwest of Tokyo and closest to urban regions, and Ryori (noted as $\mathrm{S} 3: 39.03^{\circ} \mathrm{N}$, $141.82^{\circ} \mathrm{E}$ ) which is in the north and representative of rural conditions. The model generally captured the observed pattern of $\mathrm{O}_{3}$ trends at each site. For the clean site (S1), no significant trends are inferred either in the observed or the simulated maximum of $\mathrm{DM} 8 \mathrm{O}_{3}$. However, for the urban site (S2), a significant reduction, particularly during summer, is noted in the observed values and is reflective of emission reductions in Japan during the past 2 decades (e.g., Wakamatsu (c) AIRBASE

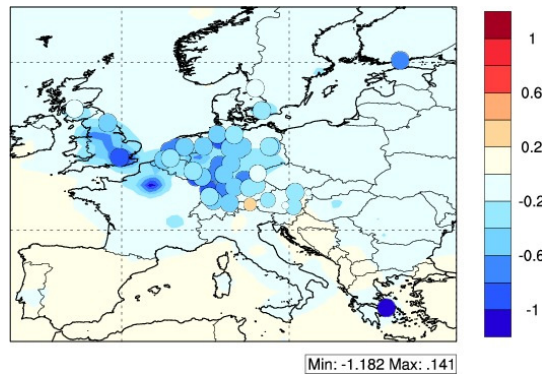

(d) EMEP

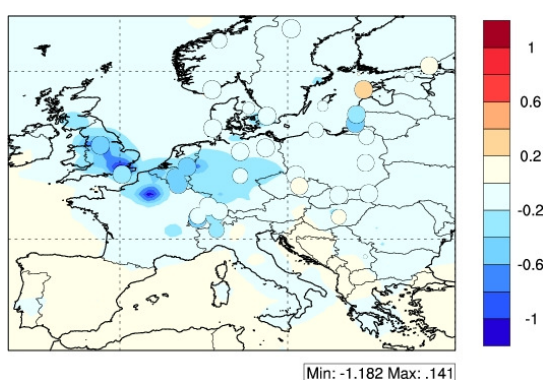

(e) AQS
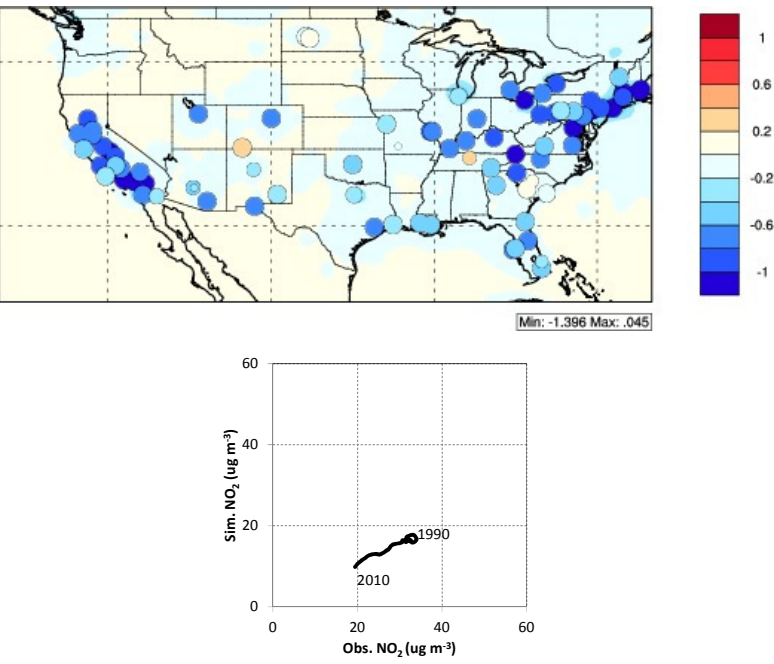

et al., 2013). In contrast, increasing trends are inferred at the rural site (S3) in all seasons expect fall, presumably representing transport from upwind locations in eastern Asia. The model produces similar magnitudes (though of smaller significance) of the decreasing/increasing trends at $\mathrm{S} 2 / \mathrm{S} 3$. The contrasting trends at sites S2 and S3 likely result from different controls in local emissions as well as transboundary transport. 


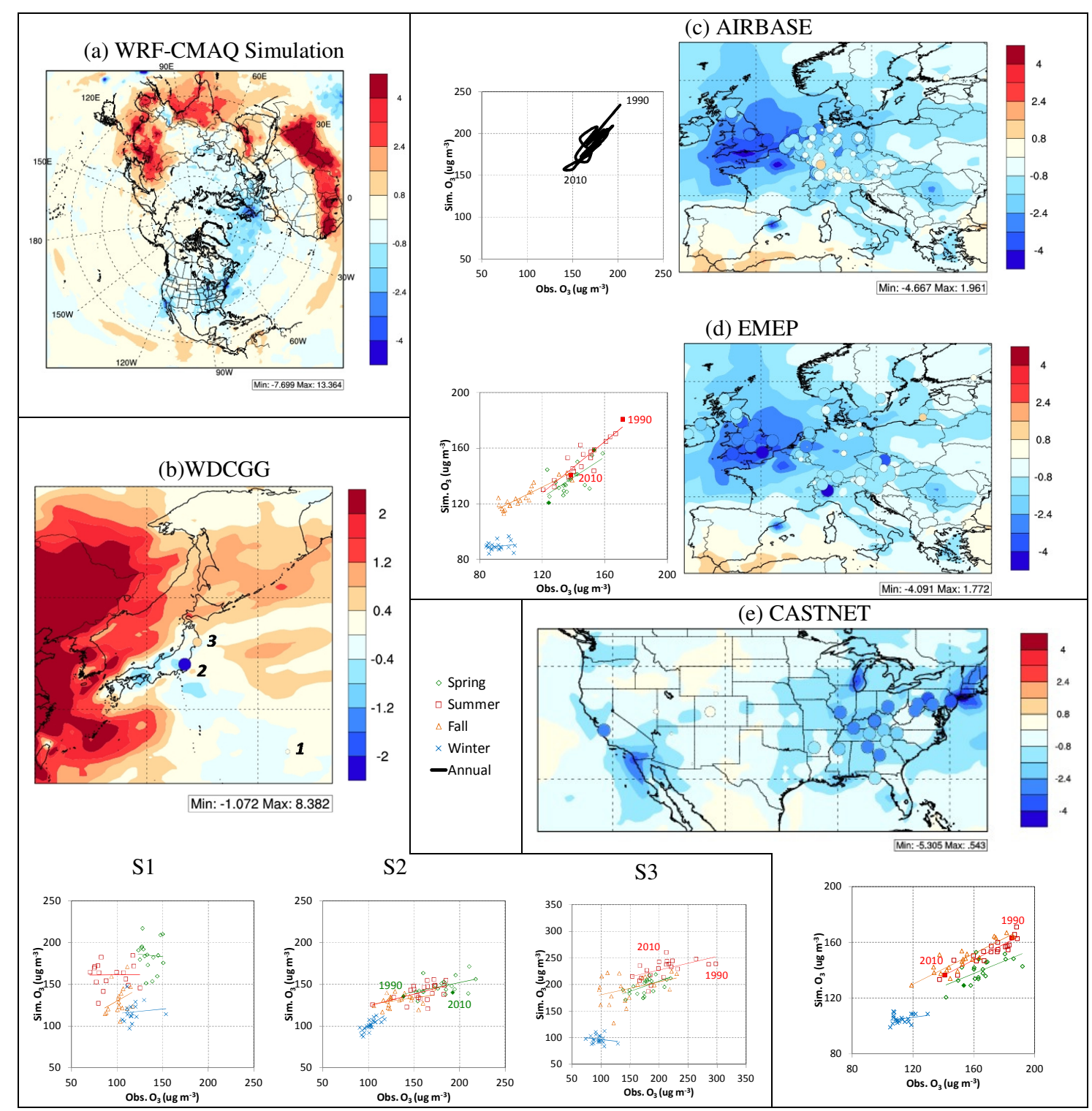

Figure 5. Same as Fig. 3 for $\mathrm{O}_{3}\left(\mu \mathrm{g} \mathrm{m}^{-3}\right.$, computed on the basis of annual or seasonal maximum of DM8 (daily $8 \mathrm{~h}$ maxima) value, except that for AIRBASE which is computed on the basis of annual maximum of DM1 (daily $1 \mathrm{~h}$ maxima); three sites of WDCGG are S1 Minamitorishima: $24.28^{\circ} \mathrm{N}, 153.98^{\circ} \mathrm{E}$; S2 - Ryori: $39.03^{\circ} \mathrm{N}, 141.82^{\circ} \mathrm{E}$; S3 - Tsukuba: $\left.36.05^{\circ} \mathrm{N}, 140.13^{\circ} \mathrm{E}\right)$.

\subsection{3 $\mathrm{SO}_{4}^{2-}, \mathrm{NO}_{3}^{-}$and $\mathrm{NH}_{4}^{+}$trends}

Simulated $\mathrm{SO}_{4}^{2-}$ shows a pronounced increasing trend in eastern China $(2.8 \%$ per year) and decrease in the US $(-3.2 \%$ per year) and EUROPE $(-3.7 \%$ per year) which is consistent with, though slightly smaller in magnitude, trends in $\mathrm{SO}_{2}$ emissions in these regions (see Table 3 and Fig. 6).

Simulated $\mathrm{SO}_{4}^{2-}$ trends are in a good agreement with observed trends inferred from all three networks. Simulated trends in $\mathrm{SO}_{4}^{2-}$ concentrations (and annual change rate) at US-CASTNET, US-IMPROVE and EU-EMEP are $-0.09 \mu \mathrm{g} \mathrm{m}^{-3} \mathrm{yr}^{-1}(-3.5 \%),-0.03 \mu \mathrm{g} \mathrm{m}^{-3} \mathrm{yr}^{-1}(-2.1 \%)$ and $-0.09 \mu \mathrm{g} \mathrm{m}^{-3} \mathrm{yr}^{-1}(-3.6 \%)$, which are comparable with the observed trends of $-0.10 \mu \mathrm{g} \mathrm{m}^{-3} \mathrm{yr}^{-1}(-2.9 \%)$, $-0.03 \mu \mathrm{g} \mathrm{m}^{-3} \mathrm{yr}^{-1} \quad(-2.4 \%)$ and $-0.10 \mu \mathrm{g} \mathrm{m}^{-3} \mathrm{yr}^{-1}$ $(-4.1 \%)$, respectively. More significant trends are noted in summer compared to other seasons because of relatively higher summertime $\mathrm{SO}_{4}^{2-}$ concentrations. Average trends at US-CASTNET are more significant than those at IMPROVE because the majority of CASTNET sites are located in the eastern US which witnessed stronger reductions in $\mathrm{SO}_{2}$ emissions. In Europe, most $\mathrm{SO}_{4}^{2-}$ reductions are found in central to eastern Europe, i.e., Germany, Czech, Poland, Hungary, the Benelux countries, Italy, and Romania. 
(a) WRF-CMAQ Simulation

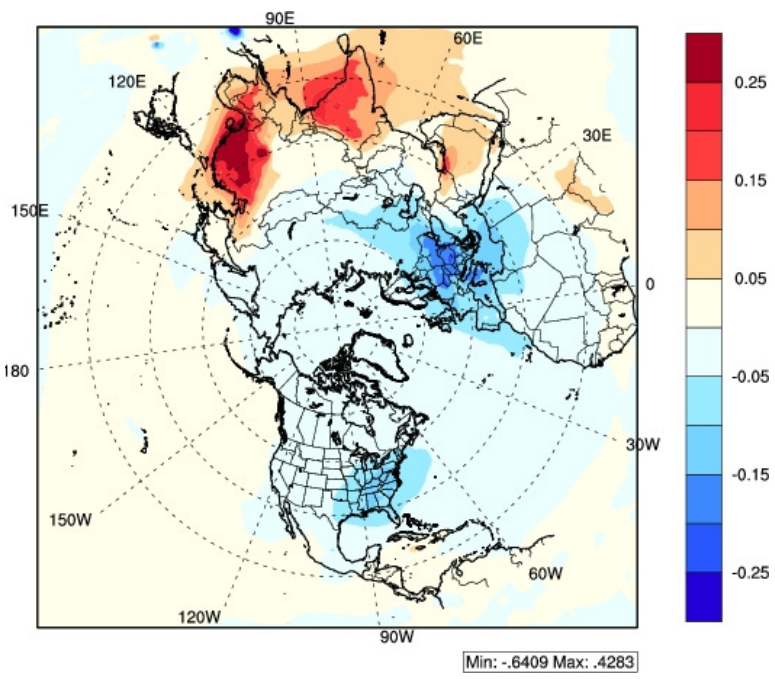

(b) EMEP
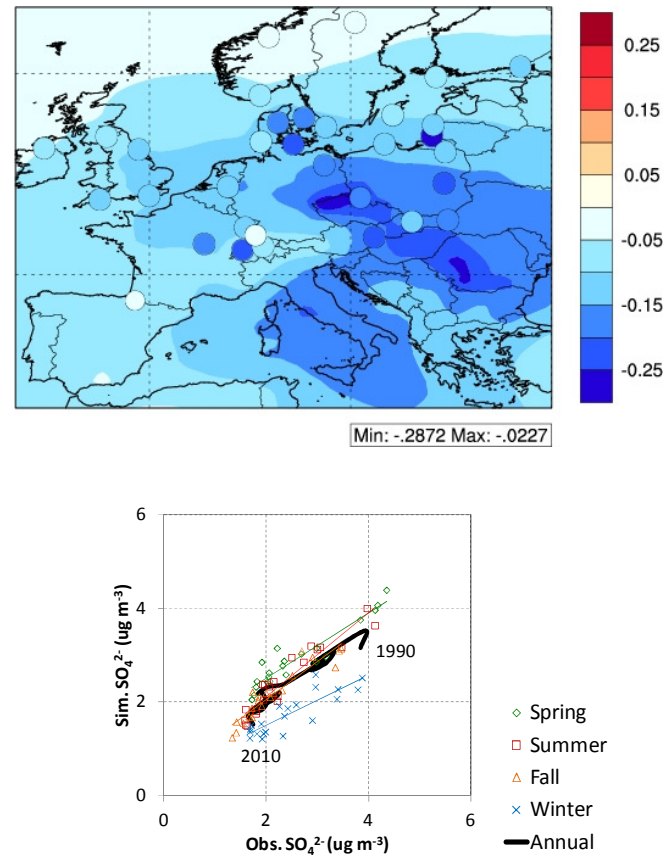

(c) CASTNET
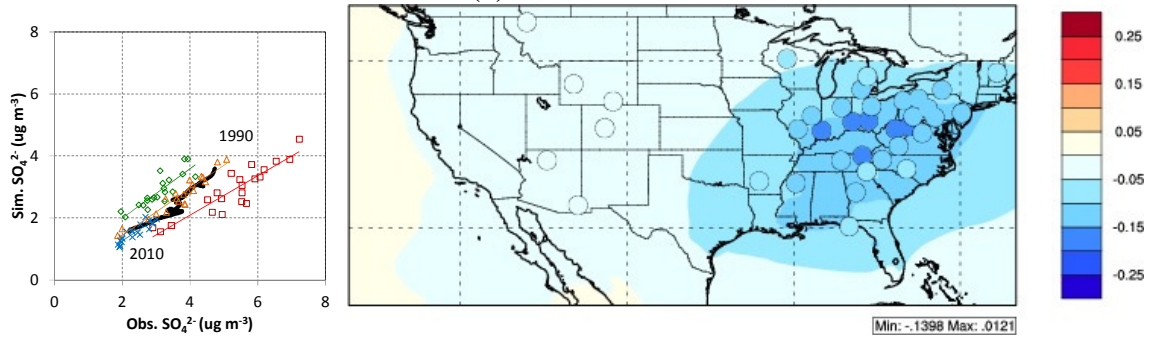

(d) IMPROVE
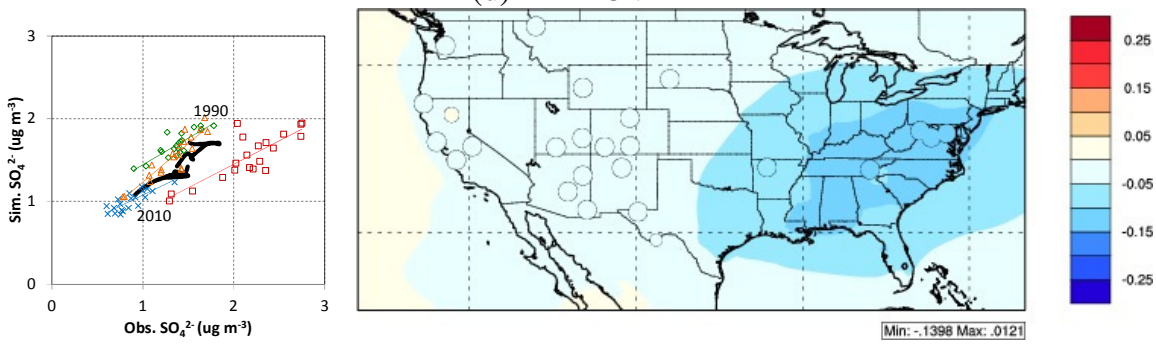

Figure 6. Same as Fig. 3 for $\mathrm{SO}_{4}^{2-}$.

$\mathrm{NH}_{3}$ emissions play an important role in $\mathrm{NO}_{3}^{-}$formation (Mathur and Dennis, 2003; Wang et al., 2011b). Growth in $\mathrm{NH}_{3}$ emissions or reduction in $\mathrm{SO}_{2}$ emissions (consequently more free $\mathrm{NH}_{3}$ due to less association with $\mathrm{SO}_{4}^{2-}$ ) without simultaneous reduction in $\mathrm{NO}_{\mathrm{x}}$ emissions can enhance $\mathrm{NO}_{3}^{-}$ concentration especially under $\mathrm{NH}_{3}$-poor conditions (Pinder et al., 2008a; Blanchard et al., 2007). As illustrated in Fig. 7, growth in both $\mathrm{NO}_{\mathrm{x}}$ and $\mathrm{NH}_{3}$ emissions results in the increasing trend in airborne $\mathrm{NO}_{3}^{-}$in China (5.4\% per year), while reductions in emissions of both results in the decreasing trend in Europe ( $-1.8 \%$ per year). In contrast, over the past 2 decades in the US, a reduction in $\mathrm{SO}_{2}$ and $\mathrm{NO}_{\mathrm{x}}$ accompanied with a growth in $\mathrm{NH}_{3}$ emission results in different trends across different seasons. The model fails to reproduce the decreasing trend in $\mathrm{NO}_{3}^{-}$at both US-CASTNET and US-IMPROVE in spring, summer and fall, though the significance of the trend is small. However, both simulated and observed $\mathrm{NO}_{3}^{-}$show an increasing trend in winter values when 
$\mathrm{NO}_{3}^{-}$is at the highest level. A similar observed increasing trend is noted during winter at the EU-EMEP monitors which is not captured by the model. The decreasing trend at the EU-EMEP locations during other seasons is, however, captured by the model. Successful reproduction of $\mathrm{NO}_{3}^{-}$trends depends on an accurate baseline emission as well as an accurate representation of changes in historical $\mathrm{NH}_{3}$ emission. Unfortunately, both current $\mathrm{NH}_{3}$ emissions and their historical trends over the globe still suffer from large uncertainties (e.g., Heald et al., 2012) and likely contribute to the significant bias in the simulated $\mathrm{NO}_{3}^{-}$trend.

$\mathrm{NH}_{4}^{+}$is simulated based on the thermodynamic equilibrium between the $\mathrm{NO}_{\mathrm{x}}, \mathrm{SO}_{\mathrm{x}}$ and $\mathrm{NH}_{\mathrm{x}}$ species. It shows a similar increasing trend in China (3.4\%) and a decreasing trend in the US $(-0.7 \%)$ and Europe $(-2.9 \%)$, as illustrated in Fig. 8. $\mathrm{NH}_{4}^{+}$simulation suffers the same uncertainties as $\mathrm{NO}_{3}^{-}$, which leads to difficulties in reproducing the trend in observations (see Table 4).

\subsubsection{Elemental carbon (EC) trends}

Growth of human activities such as biomass burning and open fires results in the simulated increasing trends in EC levels in China (1.0\%; see Table 3), India and sub-Saharan Africa (see Fig. 9). In contrast, continuous increasing controls have led to a decreasing trend in EC concentrations in the US $(-3.4 \%)$ and Europe $(-2.5 \%)$. The observed trend in EC at US-IMPROVE, i.e., $-0.006 \mu \mathrm{g} \mathrm{m}^{-3} \mathrm{yr}^{-1}(-2.6 \%)$ is well reproduced by the model, i.e., $-0.003 \mu \mathrm{g} \mathrm{m}^{-3} \mathrm{yr}^{-1}$ $(-3.3 \%)$. Both observations and the model suggest higher magnitudes of trends during fall and winter, and are likely associated with higher ambient levels during these seasons.

A decreasing trend of EC in Europe has also been observed in other studies (Järvi et al., 2008). The model estimates a consistent decreasing EC trend in the Canadian Arctic (see Fig. 9) which is mainly impacted by emissions from $\mathrm{Eu}-$ rope and Russia during winter and spring as demonstrated by Sharma et al. (2004) who analyzed in situ ground-level observations of aerosol black carbon between 1989 and 2002. The increasing trend of EC in southern Asia is corroborated by the evidence found from the Nam Co Lake (located in the central Tibetan Plateau) sediments indicating a recent rise in BC deposition flux (Cong et al., 2013).

\section{Discussion}

\section{1 $O_{3}$ chemistry}

As discussed in Sect. 3.2.2, the response of $\mathrm{O}_{3}$ concentration depends on changes in $\mathrm{NO}_{\mathrm{x}}$ and VOC emissions, and the nonlinear chemistry associated with the subsequent VOCor $\mathrm{NO}_{\mathrm{x}}$-limited environment. The response of $\mathrm{O}_{3}$ to changing levels of $\mathrm{NO}_{\mathrm{x}}$ and VOC have previously been examined through a variety of methods ranging from isopleths created from chemistry box-model calculations to detailed spatially varying response surfaces developed from output of hundreds of simulations with detailed air pollution modeling systems (e.g., Xing et al., 2011b). Exploration of the changes in $\mathrm{O}_{3}$ levels in response to historical (and geographically varying) changes in $\mathrm{NO}_{\mathrm{x}}$ and VOC emissions, as captured by the multi-decadal simulations presented here, provide a unique opportunity to develop insights into factors controlling changes in $\mathrm{O}_{3}$ production and distributions.

Figure 10 attempts to summarize the changes in $\mathrm{NO}_{\mathrm{x}}$ and VOC emissions as well as the surface $\mathrm{O}_{3}$ response during the 1990-2010 period for the three regions; the figures in the left panel illustrate the changes in emissions relative to the 1990 values and the figures in the right panel show the corresponding percentage change in both the maximum and the average of the $\mathrm{DM} 8 \mathrm{O}_{3}$ for each year. As can be noted, the relative changes in $\mathrm{NO}_{\mathrm{x}}$ and $\mathrm{VOC}$ emissions vary significantly over different time-period for different regions. Based on the emission estimates, simultaneous growth of VOC and $\mathrm{NO}_{\mathrm{x}}$ emissions is noted in China with a ratio of 0.46 (i.e., $x \% \mathrm{NO}_{\mathrm{x}}$ growth along with $0.46 x \%$ VOC growth on the basis of 1990 emission level). The modeled increases in both maximum and average of $\mathrm{DM} 8 \mathrm{O}_{3}$ values in China during this period are significant. The almost linear response seen in the trajectory of modeled $\mathrm{O}_{3}$ changes in the region over the past 2 decades suggests that control strategies that focus on combined control of $\mathrm{NO}_{\mathrm{x}}$ and VOC emissions with a ratio of 0.46 may provide the most effective means for $\mathrm{O}_{3}$ reductions for the region devoid of nonlinear response potentially associated with $\mathrm{NO}_{\mathrm{x}}$ or VOC limitation resulting from alternate strategies. The ratio suggested is less than 1 , indicating greater sensitivity of ozone to $\mathrm{NO}_{\mathrm{x}}$ emissions than VOC emissions. It is also obvious to see that the rate of $\mathrm{O}_{3}$ increase was much smaller during 1995-2002 which was the period when VOC emission growth was much greater than that of $\mathrm{NO}_{\mathrm{x}}$ emissions in China.

In contrast, trends in emissions over the eastern US indicate significant reductions in VOC emissions compared to $\mathrm{NO}_{\mathrm{x}}$ prior to $2000 . \mathrm{NO}_{\mathrm{x}}$ emissions increased slightly during 1996-2000, and then decreased significantly resulting from regional control measures. The change of $\mathrm{O}_{3}$ during the first decade (1990-2000) when VOC controls were dominant (reduction ratio of $\mathrm{VOC}$ and $\mathrm{NO}_{\mathrm{x}}$ of -42 and $-4 \%$, respectively) is smaller $(-2 \%)$ than that in the subsequent decade (2000-2010) when $\mathrm{NO}_{\mathrm{x}}$ controls were dominant (reduction ratio of VOC and $\mathrm{NO}_{\mathrm{x}}$ is -13 and $-33 \%$, respectively), leading to an estimated reduction of $-11 \%$ in ambient $\mathrm{O}_{3}$. Additionally, model simulations also show an increase in $\mathrm{O}_{3}$ during 1997-1999, when $\mathrm{NO}_{\mathrm{x}}$ emissions were estimated to increase. Thus, the response of $\mathrm{O}_{3}$ is more sensitive to changes in $\mathrm{NO}_{\mathrm{x}}$ emissions in the eastern US. The relative abundance of biogenic $\mathrm{VOC}$ emissions that tend to reduce the effectiveness of VOC controls contributes to this differing response. 
(a) WRF-CMAQ Simulation

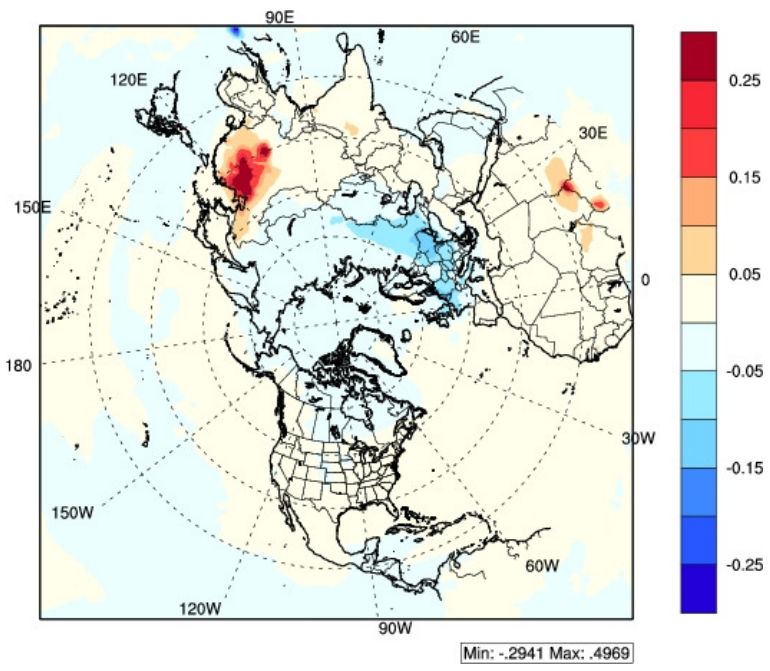

(b) EMEP
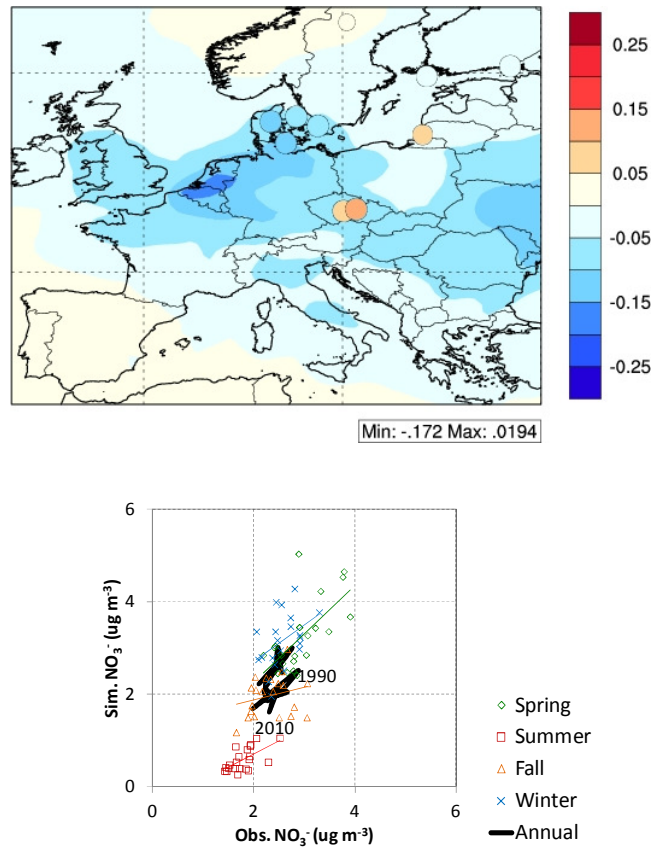

(c) CASTNET
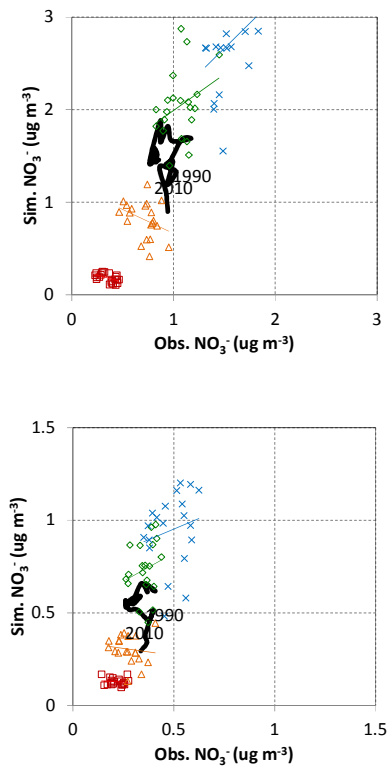

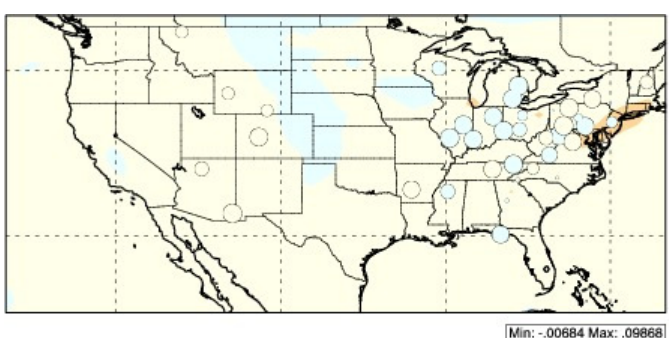

(d) IMPROVE

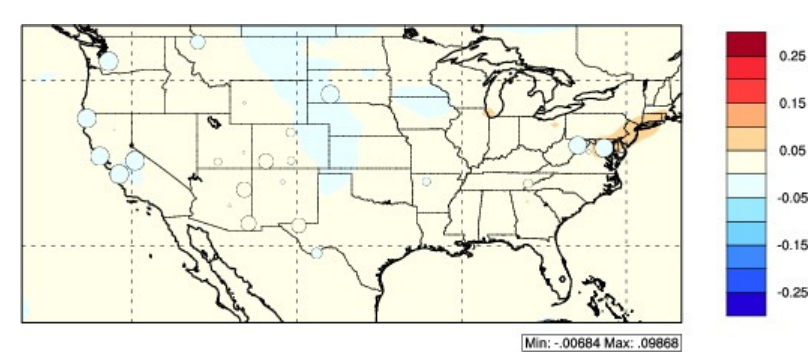

Figure 7. Same as Fig. 3 for $\mathrm{NO}_{3}^{-}$.

In Europe, simultaneous control of $\mathrm{NO}_{\mathrm{x}}$ and $\mathrm{VOC}$ with a ratio of 1.8 during 1990-2010 result in systematic reductions in ambient $\mathrm{O}_{3}$ levels. Interestingly, the reductions in the annual maximum of the regionally averaged $\mathrm{DM} 8 \mathrm{O}_{3}$ are much greater than those of the corresponding annual mean DM8 $\mathrm{O}_{3}$, indicating the impact of emission reductions in the region on reducing peak $\mathrm{O}_{3}$ during regional pollution episodes. During the period 2000-2007 when solely VOC emissions reduced $(-10 \%)$, no significant reduction in either annual maximum or average of DM8 $\mathrm{O}_{3}$ values occurred. Reductions in $\mathrm{NO}_{\mathrm{x}}(-10 \%)$ with $\mathrm{VOC}(-5 \%)$ emissions in the subsequent 2007 to 2010 period lead to reductions in both maximum and average of $\mathrm{DM} 8 \mathrm{O}_{3}$ values. 
(a) WRF-CMAQ Simulation

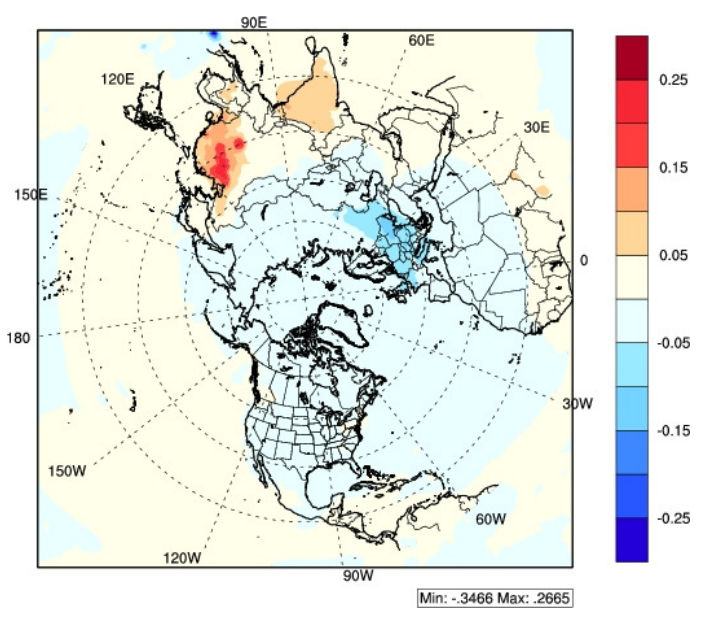

(b) EMEP
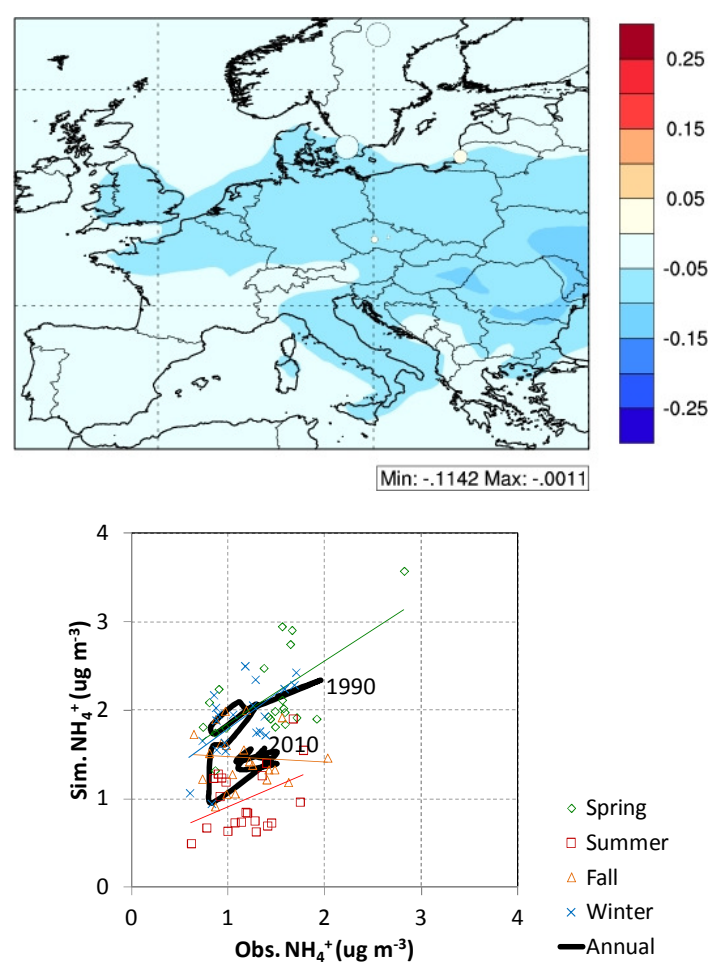

(b) CASTNET
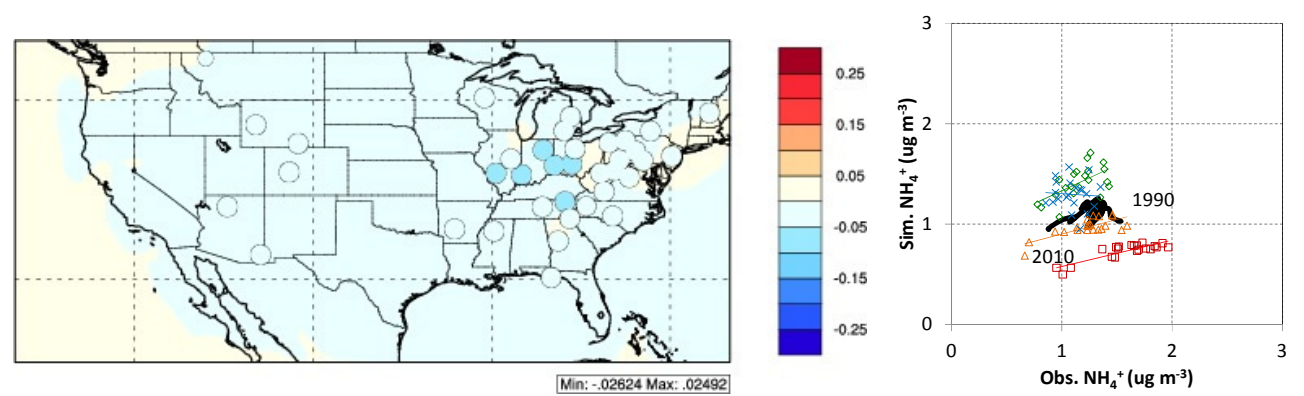

Figure 8. Same as Fig. 3 for $\mathrm{NH}_{4}^{+}$.

\subsection{PM chemistry}

The nonlinear response of $\mathrm{NO}_{3}^{-}$concentration to $\mathrm{SO}_{2}, \mathrm{NO}_{\mathrm{x}}$ and $\mathrm{NH}_{3}$ emissions is well documented (e.g., Mathur and Dennis, 2003; Tsimpidi et al., 2007; Makar et al., 2009). Figure 11 attempts to summarize the changes in emissions and factors driving the $\mathrm{NO}_{\mathrm{x}}-\mathrm{SO}_{\mathrm{x}}-\mathrm{NH}_{\mathrm{x}}$ system and its influence on changing inorganic particulate matter composition for the three regions. Contrasting trends in emissions over the past 2 decades in the three regions are apparent: while China and many growing regions of Asia have witnessed significant increases in emissions of $\mathrm{NO}_{\mathrm{x}}, \mathrm{SO}_{2}$, and $\mathrm{NH}_{3}$, significant reductions in emissions of all these species have occurred in Europe. In contrast, in the eastern US, while combustion- related emissions of $\mathrm{NO}_{\mathrm{x}}$ and $\mathrm{SO}_{2}$ have declined, growth in agricultural animal husbandry have resulted in significant increases in $\mathrm{NH}_{3}$ emissions. To examine the impact of the varying emissions patterns on inorganic particulate matter formation and composition in these regions, we examined trends in two metrics relative to their 1990 values: (i) the degree of sulfate neutralization, an estimate of the neutralization of sulfate by ammonium (Pinder et al., 2008b; DSN $=\left(\left[\mathrm{NH}_{4}^{+}\right]\right.$ $\left.\left.-\left[\mathrm{NO}_{3}^{-}\right]\right) /\left[\mathrm{SO}_{4}^{2-}\right]\right)$, and (ii) a new metric, the "nitration ratio (NR)" (i.e., $\mathrm{NO}_{3}^{-}$concentration divided by $\mathrm{NO}_{\mathrm{x}}$ emission) to represent the relative amount of oxidized-N emissions that is eventually transformed to aerosol $\mathrm{NO}_{3}^{-}$; changes in the ratio could thus be viewed as an indicator of the relative effectiveness of $\mathrm{NO}_{\mathrm{x}}$ controls for given conditions. Figure 11 presents 
(a) WRF-CMAQ Simulation

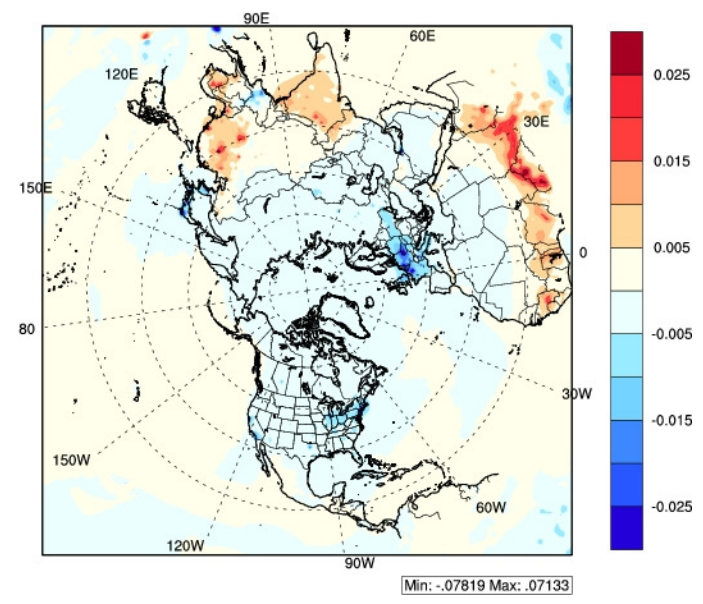

(b) IMPROVE
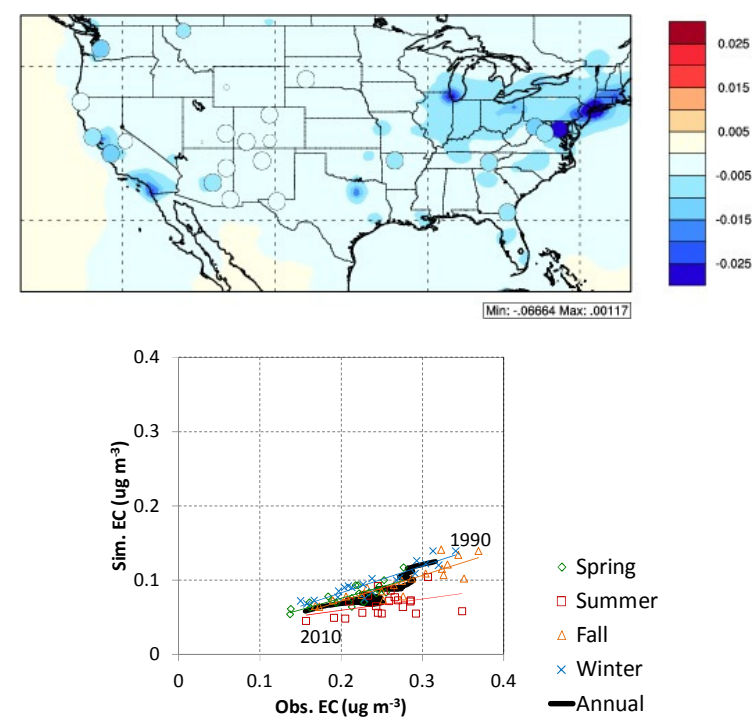

Figure 9. Same as Fig. 3 for EC.

the response of PM chemistry to the changes in emissions as indicated by the trends in these metrics during the period 1990-2010.

In eastern China, simultaneous growth of $\mathrm{NH}_{3}$ emission with $\mathrm{SO}_{2}$ and $\mathrm{NO}_{\mathrm{x}}$ plays a very important role in the increases of $\mathrm{SO}_{4}^{2-}$ and $\mathrm{NO}_{3}^{-}$concentrations (Wang et al., 2011b). During the period 1993-2002, the rate of increase in $\mathrm{NH}_{3}$ emissions is greater than that of $\mathrm{NO}_{\mathrm{x}}+2 \times \mathrm{SO}_{2}$ emissions (representing the amount of $\mathrm{NH}_{3}$ needed for complete neutralization), with a ratio of 1.1 (i.e., $x \%\left(\mathrm{NO}_{\mathrm{x}}+2 \mathrm{SO}_{2}\right)$ growth along with $1.1 x \% \mathrm{NH}_{3}$ growth on the basis of 1990 emission level). In these $\mathrm{NH}_{3}$-rich conditions, both DSN and NR consequently exhibit an increasing trend, suggesting that sufficient $\mathrm{NH}_{3}$ was available to neutralize the available and increasing aerosol $\mathrm{SO}_{4}^{2-}$ and also enable formation of particulate $\mathrm{NO}_{3}^{-}$. The increasing trend in $\mathrm{NR}$ for this region also indicate that the simultaneous growth in emissions of both reduced and oxidized nitrogen results in a greater fraction of $\mathrm{NO}_{\mathrm{x}}$ being eventually transformed to particulate $\mathrm{NO}_{3}^{-}$. After 2002, both DSN and NR decline when the growth of $\mathrm{NO}_{\mathrm{x}}+2 \times \mathrm{SO}_{2}$ emissions is faster than that of $\mathrm{NH}_{3}$ (ratio of 0.9 ), resulting in the decline of the DSN and NR, eventually back to the 1990-levels.

In contrast, in the eastern US, both DSN and NR exhibit a steady increase during the entire 21-year period, suggesting progressively richer $\mathrm{NH}_{3}$ conditions stemming from both increased $\mathrm{NH}_{3}$ emissions as well as more free $\mathrm{NH}_{3}$ being available due to reduced $\mathrm{SO}_{4}^{2-}$ levels associated with declining $\mathrm{SO}_{2}$ emissions. Steadily increasing trends in NR values also suggest that increasing $\mathrm{NH}_{3}$ levels offset the relative effectiveness of $\mathrm{NO}_{\mathrm{x}}$ controls in reducing the relative fraction of aerosol $\mathrm{NO}_{3}^{-}$formed from declining $\mathrm{NO}_{\mathrm{x}}$ emissions.
Interestingly, in Europe simultaneous control of $\mathrm{NH}_{3}$ along with $\mathrm{NO}_{\mathrm{x}}$ and $\mathrm{SO}_{2}$ emissions yields an emission change ratio of 0.6 (i.e., $x \%\left(\mathrm{NO}_{\mathrm{x}}+2 \mathrm{SO}_{2}\right)$ reduction along with $0.6 x \%$ reduction of $\mathrm{NH}_{3}$ on the basis of 1990 emission level). Though a slight increase of DSN is simulated during 1992-2003 resulting from faster growth of $\mathrm{NO}_{\mathrm{x}}$ and $\mathrm{SO}_{2}$ compared to $\mathrm{NH}_{3}$, there is no discernable trend in the estimated NR suggesting comparatively greater control effectiveness in this region compared to the other two, due to the simultaneous control of $\mathrm{NH}_{3}$ with combustion-related emissions of $\mathrm{NO}_{\mathrm{x}}$ and $\mathrm{SO}_{2}$.

\section{Conclusions}

Trends in air quality across the Northern Hemisphere from 1990 to 2010 have been simulated by the WRF-CMAQ model driven with a representation of historical emission inventories derived from the EDGAR. Thorough comparison with several surface observation networks mostly in Europe and North America has been conducted. Significant contrasting changes in emissions have occurred across the Northern Hemisphere over the past 2 decades with reductions in North America and western Europe resulting from control measures on combustion-related sources and increases across large parts of Asia associated with economic and population growth. Model calculations show associated contrasting trends in air pollution across the Northern Hemisphere emphasizing the changing tropospheric composition of trace pollutants as well as the potentially changing background pollution levels in different regions resulting from changes in the amounts of long-range transported pollution. The model 
Emission
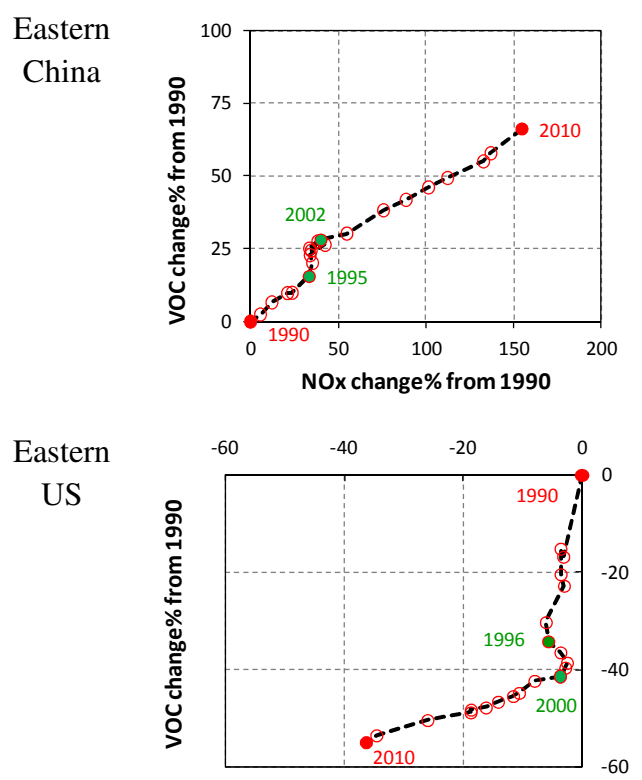

NOx change\% from 1990

Europe

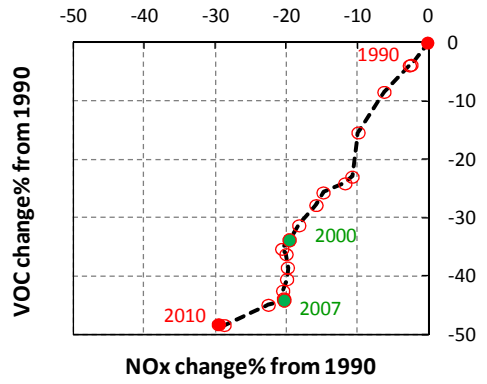

Figure 10. Changes in $\mathrm{O}_{3}$ chemistry from modeling results.

is generally able to capture the observed trends in air pollution, and performance statistics are comparable with results from other studies in regions across the Northern Hemisphere. However, the model estimates still suffer from uncertainties in emissions (in regards to temporal variation and speciation), coarse spatial resolution and subsequent impacts on representation of nonlinear atmospheric chemistry. The lightening $\mathrm{NO}_{\mathrm{x}}$ emissions used in this study (Price et al., 1997) are likely overestimated compared to a more recent study (Schumann and Huntrieser et al., 2007) and may contribute, to some extent, to the overestimation of $\mathrm{NO}_{\mathrm{x}}, \mathrm{O}_{3}$ and nitrate concentrations. The trend of biogenic emissions, which has not been considered in this study, might also impact the analysis. The lack of long-term observations in Asia, particularly over China and India, limits a robust model performance evaluation and $\mathrm{O}_{3}$ and $\mathrm{PM}$ chemistry assessment in these polluted areas. To explore the limitation of coarse spatial resolution in the future, we are currently conducting a study with a finer-scale simulation over the continental
Response
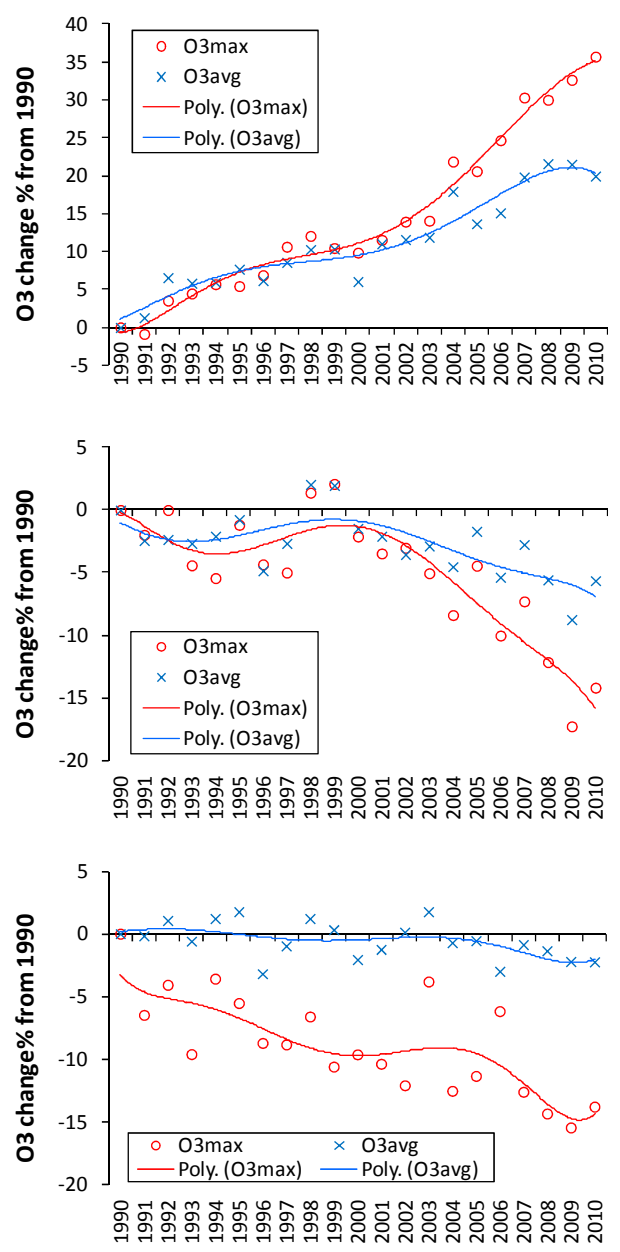

United States domain for the same simulated period as from 1990 to 2010. A detailed description and comparison will be provided in a separate paper (Gan et al., 2015).

Model-simulated air quality trends over the past 2 decades largely agree with those derived from observations. Significant reductions in ambient levels of most pollutants have been seen in the US and Europe resulting from emission controls implemented during 1990-2010, while levels of all pollutants in China show pronounced increasing trends during the same period. Examining the simulated and observed historical trends in atmospheric chemistry can help guide development of future air pollution abatement strategies. Model calculations over the 1990-2010 period suggest that in the relative amounts of $\mathrm{VOC}$ and $\mathrm{NO}_{\mathrm{x}}$ emission controls in different regions across the Northern Hemisphere (eastern US, Europe and China), have led to significantly different trends in tropospheric $\mathrm{O}_{3}$ in these regions. In particular, steady increases in $\mathrm{NO}_{\mathrm{x}}$ and VOC emissions (with a ratio of 0.46 relative to 1990 emissions) in China have resulted in a near-linear 

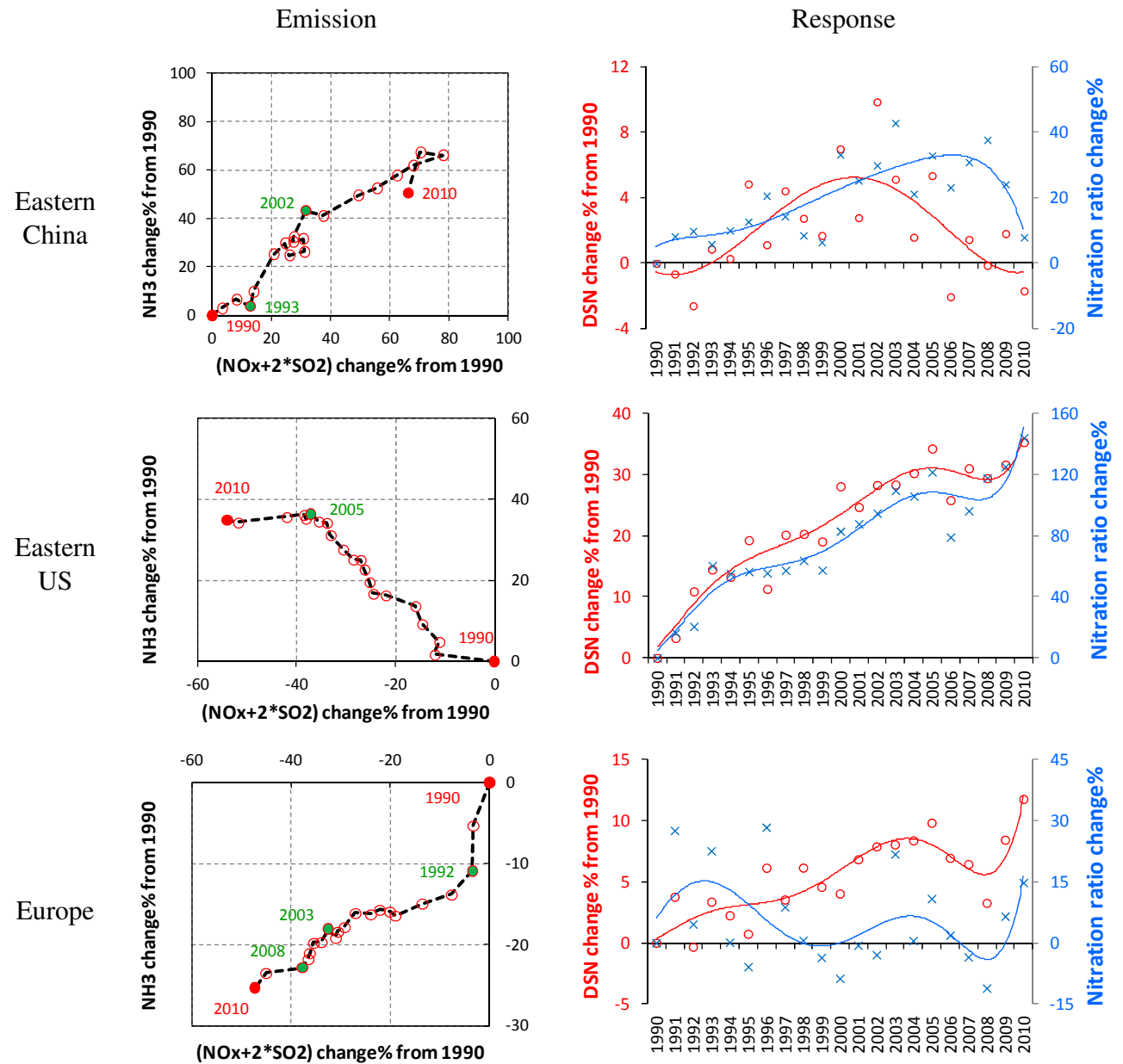

Figure 11. Changes in PM chemistry from modeling results (calculation based on molecular units; grid-averaged for three regions; $\left(\mathrm{NO}_{\mathrm{x}}+2 * \mathrm{SO}_{2}\right)$ represents the amount of $\mathrm{NH}_{3}$ needed for complete neutralization; DSN - degree of sulfate neutralization; nitration ratio = $\mathrm{NO}_{3}^{-}$concentration / $\mathrm{NO}_{\mathrm{x}}$ emission).

increase in surface $\mathrm{O}_{3}$ concentrations in the region, suggesting that possible control strategies that maintain this relative ratio could potentially be most effective in avoiding a nonlinear response resulting from VOC-limitation of alternate approaches. Differences in the historical changes in the relative amounts of $\mathrm{NH}_{3}, \mathrm{NO}_{\mathrm{x}}$ and $\mathrm{SO}_{2}$ emissions in these regions also impact the trends in inorganic particulate matter amounts and composition in these regions. In particular, the amount of particulate nitrate formed per unit of $\mathrm{NO}_{\mathrm{x}}$ emissions is influenced by changing $\mathrm{NH}_{3}$ emissions and could be important in assessing the relative effectiveness of different control strategies. Simultaneous growth of $\mathrm{NH}_{3}$ emission along with those of $\mathrm{NO}_{\mathrm{x}}$ and $\mathrm{SO}_{2}$ in China over the past 2 decades has resulted in the increasing particulate nitrate formation trends in the region. In contrast, in the eastern US, the relative fraction of $\mathrm{NO}_{\mathrm{x}}$ converted to particulate nitrate exhibits a steady increase over the past 2 decades, suggesting an offset in the relative effectiveness of control measures on particulate nitrate levels in the region. Simultaneous reduc- tions in $\mathrm{NH}_{3}$ emissions along with those of $\mathrm{NO}_{\mathrm{x}}$, and $\mathrm{SO}_{2}$ in western Europe over the past 2 decades resulted in no significant trend in nitration ratio, suggesting the effectiveness of the overall measures in terms of particulate nitrate levels in the region.

Acknowledgements. Although this work has been reviewed and approved for publication by the US Environmental Protection Agency (EPA), it does not reflect the views and policies of the agency. This work was supported in part by an inter-agency agreement between the US Department of Energy project (IA no. DE-SC000378) and the US EPA (IA no. RW-89-9233260 1). This research was performed while Jia Xing held a National Research Council Research Associateship Award at the US EPA. The authors gratefully acknowledge the free availability and use of data sets associated with the EDGAR, SMOKE, GEIA, CASTNET, IMPROVE, AQS, EMEP, AIRBASE, WDCGG and China API initiatives.

Edited by: Y. Balkanski 


\section{References}

Akimoto, H., Ohara, T., Kurokawa, J. I., and Horii, N.: Verification of energy consumption in China during 1996-2003 by using satellite observational data, Atmos. Environ., 40, 7663-7667, 2006.

Appel, K. W., Gilliland, A. B., Sarwar, G., and Gilliam, R. C.: Evaluation of the Community Multiscale Air Quality (CMAQ) model version 4.5: sensitivities impacting model performance: part I-ozone, Atmos. Enviro., 41, 9603-9615, 2007.

Appel, K. W., Bhave, P. V., Gilliland, A. B., Sarwar, G., and Roselle, S. J.: Evaluation of the community multiscale air quality (CMAQ) model version 4.5: sensitivities impacting model performance; Part II - Particulate matter, Atmos. Environ., 42, 6057-6066, 2008.

Binkowski, F. S. and Roselle, S. J.: Community Multiscale Air Quality (CMAQ) model aerosol component, I: Model description, J. Geophys. Res., 108, 4183, doi:10.1029/2001JD001409, 2003.

Blanchard, C. L., Tanenbaum, S., and Hidy, G. M.: Effects of Sulfur Dioxide and Oxides of Nitrogen Emission Reductions on Fine Particulate Matter Mass Concentrations: Regional Comparisons, J. Air Waste Manage., 57, 1337-1350, 2007.

Butler, T. J. and Lakens, G. E.: The impact of changing regional emissions on precipitation chemistry in the eastern United States, Atmos. Environ. A-Gen., 25, 305-315, 1991

Byun, D. and Schere, K. L.: Review of the governing equations, computational algorithms, and other components of the Models3 Community Multiscale Air Quality (CMAQ) modeling system, Appl. Mech. Rev., 59, 51-77, 2006.

Chameides, W. L., Fehsenfeld, F., Rodgers, M. O., Cardelino, C., Martinez, J., Parrish, D., Lonneman, W., Lawson, D. R., Rasmussen, R. A., Zimmerman, P., Greenberg, J., Mlddleton, P., and Wang, T.: Ozone precursor relationships in the ambient atmosphere, J. Geophys. Res.-Atmos., 97, 6037-6055, 1992.

Civerolo, K., Hogrefe, C., Zalewsky, E., Hao, W., Sistla, G., Lynn, B., Rosenzweig, C., and Kinney, P. L.: Evaluation of an 18-year CMAQ simulation: Seasonal variations and long-term temporal changes in sulfate and nitrate, Atmos. Environ., 44, 3745-3752, 2010.

Colette, A., Granier, C., Hodnebrog, Ø., Jakobs, H., Maurizi, A., Nyiri, A., Bessagnet, B., D’Angiola, A., D’Isidoro, M., Gauss, M., Meleux, F., Memmesheimer, M., Mieville, A., Rouill, L., Russo, F., Solberg, S., Stordal, F., and Tampieri, F.: Air quality trends in Europe over the past decade: a first multi-model assessment, Atmos. Chem. Phys., 11, 11657-11678, doi:10.5194/acp11-11657-2011, 2011.

Cong, Z., Kang, S., Gao, S., Zhang, Y., Li, Q., and Kawamura, K.: Historical trends of atmospheric black carbon on Tibetan Plateau as reconstructed from a 150-year lake sediment record, Environ. Sci. Technol., 47, 2579-2586, 2013.

Ding, A. J., Wang, T., Thouret, V., Cammas, J.-P., and Nédélec, P.: Tropospheric ozone climatology over Beijing: analysis of aircraft data from the MOZAIC program, Atmos. Chem. Phys., 8, 1-13, doi:10.5194/acp-8-1-2008, 2008.

Eder, B. and Yu, S.: A performance evaluation of the 2004 release of Models-3 CMAQ, Atmos. Environ., 40, 4811-4824, 2006.

EEA (European Environment Agency): European Union emission inventory report 1990-2010 under the UNECE Convention on Long-range Transboundary Air Pollution (LRTAP), EEA Tech- nical report, 30 July, Copenhagen, Denmark, doi:10.2800/5219, 2012.

Emery, C., Tai, E., and Yarwood, G.: Enhanced meteorological modeling and performance evaluation for two texas episodes. Report to the Texas Natural Resources Conservation Commission ENVIRON, International Corp Novato, CA, 2001.

European Commission: Joint Research Centre (JRC)/Netherlands Environmental Assessment Agency (PBL). Emission Database for Global Atmospheric Research (EDGAR), release version 4.2., available at: http://edgar.jrc.ec.europa.eu (last access: 25 September 2014), 2011.

Foley, K. M., Roselle, S. J., Appel, K. W., Bhave, P. V., Pleim, J. E., Otte, T. L., Mathur, R., Sarwar, G., Young, J. O., Gilliam, R. C., Nolte, C. G., Kelly, J. T., Gilliland, A. B., and Bash, J. O.: Incremental testing of the Community Multiscale Air Quality (CMAQ) modeling system version 4.7, Geosci. Model Dev., 3, 205-226, doi:10.5194/gmd-3-205-2010, 2010.

Gan, C.-M., Pleim, J., Mathur, R., Hogrefe, C., Long, C. N., Xing, J., Roselle, S., and Wei, C.: Assessment of the effect of air pollution controls on trends in shortwave radiation over the United States from 1995 through 2010 from multiple observation networks, Atmos. Chem. Phys., 14, 1701-1715, doi:10.5194/acp14-1701-2014, 2014.

Gan, C.-M., Pleim, J., Mathur, R., Hogrefe, C., Long, C. N., Xing, J., Wong, D., Gilliam, R., Roselle, S. J., and Wei, C.: Assessment of long-term simulations with various observations for better understanding of aerosol effects on radiation "brightening" in the United States, the 95th AMS Annual Meeting, Phoenix, AZ, 4-8 January, 2015.

Guenther, A., Hewitt, C. N., Erickson, D., Fall, R., Geron, C., Graedel, T., Harley, P., Klinger, L., Lerdau, M., McKay, W. A., Pierce, T., Scholes, B., Steinbrecher, R., Tallamraju, R., Taylor, J., and Zimmerman, P.: A Global Model of Natural Volatile Organic Compound Emissions, J. Geophys. Res., 100, 8873-8892, 1995.

He, K. B.: Multi-resolution Emission Inventory for China (MEIC): model framework and 1990-2010 anthropogenic emissions, International Global Atmospheric Chemistry Conference, 17-21 September, Beijing, China, S1-I-2, 2012.

Heald, C. L., Collett Jr., J. L., Lee, T., Benedict, K. B., Schwandner, F. M., Li, Y., Clarisse, L., Hurtmans, D. R., Van Damme, M., Clerbaux, C., Coheur, P.-F., Philip, S., Martin, R. V., and Pye, H. O. T.: Atmospheric ammonia and particulate inorganic nitrogen over the United States, Atmos. Chem. Phys., 12, 10295-10312, doi:10.5194/acp-12-10295-2012, 2012.

Hogrefe, C., Lynn, B., Goldberg, R., Rosenzweig, C., Zalewsky, E., Hao, W., Doraiswamy, P., Civerolo, K., Ku, J.-Y., Sistla, G., and Kinney, P. L.: A combined model-observation approach to estimate historic gridded fields of $\mathrm{PM}_{2.5}$ mass and species concentrations, Atmos. Environ., 43, 2561-2570, 2009.

Hogrefe, C., Hao, W., Zalewsky, E. E., Ku, J.-Y., Lynn, B., Rosenzweig, C., Schultz, M. G., Rast, S., Newchurch, M. J., Wang, L., Kinney, P. L., and Sistla, G.: An analysis of long-term regional-scale ozone simulations over the Northeastern United States: variability and trends, Atmos. Chem. Phys., 11, 567-582, doi:10.5194/acp-11-567-2011, 2011.

Iacono, M. J., Delamere, J. S., Mlawer, E. J., Shephard, M. W., Clough, S. A., and Collins, W. D.: Radiative forcing by long-lived greenhouse gases: Calculations with the AER 
radiative transfer models, J. Geophys. Res., 113, D13103, doi:10.1029/2008JD009944, 2008.

Irie, H., Sudo, K., Akimoto, H., Richter, A., Burrows, J. P., Wagner, T., Wenig, M., Beirle, S., Kondo, Y., Sinyakov, V. P., and Goutail, F.: Evaluation of long-term tropospheric NO2 data obtained by GOME over East Asia in 1996-2002, Geophys. Res. Lett., 32, L11810, doi:10.1029/2005GL022770, 2005.

Jaffe, D. and Ray, J.: Increase in surface ozone at rural sites in the western US, Atmos. Environ., 41, 5452-5463, 2007.

Janssens-Maenhout, G., Dentener, F., Van Aardenne, J., Monni, S., Pagliari, V., Orlandini, L., Klimont, Z., Kurokawa, J., Akimoto, H., Ohara, T., Wankmueller, R., Battye, B., Grano, D., Zuber, A., and Keating, T.: EDGAR-HTAP: a Harmonized Gridded Air Pollution Emission Dataset Based on National Inventories, European Commission Publications Office, Ispra, Italy, EUR report no. EUR 25229, 2012.

Järvi, L., Junninen, H., Karppinen, A., Hillamo, R., Virkkula, A., Mäkelä, T., Pakkanen, T., and Kulmala, M.: Temporal variations in black carbon concentrations with different time scales in Helsinki during 1996-2005, Atmos. Chem. Phys., 8, 1017-1027, doi:10.5194/acp-8-1017-2008, 2008.

Jiang, D. H., Zhang, Y., Hu, X., Zeng, Y., Tan, J. G., and Shao, D. M.: Progress in developing an ANN model for air pollution index forecasting, Atmos. Environ., 28, 7055-7064, 2004.

Koumoutsaris, S. and Bey, I.: Can a global model reproduce observed trends in summertime surface ozone levels?, Atmos. Chem. Phys., 12, 6983-6998, doi:10.5194/acp-12-6983-2012, 2012.

Kukkonen, J., Olsson, T., Schultz, D. M., Baklanov, A., Klein, T., Miranda, A. I., Monteiro, A., Hirtl, M., Tarvainen, V., Boy, M., Peuch, V.-H., Poupkou, A., Kioutsioukis, I., Finardi, S., Sofiev, M., Sokhi, R., Lehtinen, K. E. J., Karatzas, K., San José, R., Astitha, M., Kallos, G., Schaap, M., Reimer, E., Jakobs, H., and Eben, K.: A review of operational, regional-scale, chemical weather forecasting models in Europe, Atmos. Chem. Phys., 12, 1-87, doi:10.5194/acp-12-1-2012, 2012.

Logan, J. A., Staehelin, J., Megretskaia, I. A., Cammas, J.-P., Thouret, V., Claude, H., De Backer, H., Steinbacher, M., Scheel, H. E., Stübi, R., Fröhlich, M., and Derwent, R.: Changes in ozone over Europe: analysis of ozone measurements from sondes, regular aircraft (MOZAIC) and alpine surface sites, J. Geophys. Res., 117, D09301, doi:10.1029/2011JD016952, 2012.

Luo, C., Wang, Y. H., Mueller, S., and Knipping, E.: Diagnosis of an underestimation of summertime sulfate using the Community Multiscale Air Quality model, Atmos. Environ., 45, 5119-5130, 2011.

Makar, P. A., Moran, M. D., Zheng, Q., Cousineau, S., Sassi, M., Duhamel, A., Besner, M., Davignon, D., Crevier, L.-P., and Bouchet, V. S.: Modelling the impacts of ammonia emissions reductions on North American air quality, Atmos. Chem. Phys., 9, 7183-7212, doi:10.5194/acp-9-7183-2009, 2009.

Mathur, R. and Dennis, R. L.: Seasonal and annual modeling of reduced nitrogen compounds over the eastern United States: Emissions, ambient levels, and deposition amounts, J. Geophys. Res.Atmos., 108, 4481, doi:10.1029/2002JD002794, 2003.

Mathur, R., Yu, S., Kang, D., and Schere, K. L.: Assessment of the wintertime performance of developmental particulate matter forecasts with the Eta - Community Multiscale Air Qual- ity modeling system, J. Geophys. Res.-Atmos., 113, D02303, doi:10.1029/2007JD008580, 2008.

Mathur, R., Gilliam, R., Bullock, O. R., Roselle, S., Pleim, J., Wong, D., Binkowski, F., and Streets, D.: Extending the applicability of the community multiscale air quality model to hemispheric scales: motivation, challenges, and progress, in: Air pollution modeling and its applications, edited by: Steyn, D. G. and Trini, S., XXI. Springer, Dordrecht, 175-179, 2012.

Mathur, R., Roselle, S., Young, J., and Kang, D.: Representing the Effects of Long-Range Transport and Lateral Boundary Conditions in Regional Air Pollution Models, Air Pollution Modeling and its Application XXII NATO Science for Peace and Security Series C: Environmental Security, Springer, Heidelburg, Germany, Chapter 51, 303-308, 2014.

Matthias, V., Aulinger, A., Bieser, J., Cuesta, J., Geyer, B., Langmann, B., Serikov, I., Mattis, I., Minikin, A., Mona, L., Quante, M., Schumann, U., and Weinzierl, B.: The ash dispersion over Europe during the Eyjafjallajökull eruption - comparison of CMAQ simulations to remote sensing and air-borne in-situ observations, Atmos. Environ. 48, 184-194, 2012.

Ott, L. E., Pickering, K. E., Stenchikov, G. L., Allen, D. J., DeCaria, A. J., Ridley, B., Lin, R.-F., Lang, S., and Tao, W.K.: Production of lightning $\mathrm{NO}(\mathrm{x})$ and its vertical distribution calculated from three-dimensional cloud-scale chemical transport model simulations, J. Geophys. Res.-Atmos., 115, D04301, doi:10.1029/2009jd011880, 2010.

Pandis, S. N. and Seinfeld, J. H.: Sensitivity analysis of a chemical mechanism for aqueous-phase atmospheric chemistry, J. Geophys. Res.-Atmos., 94, 1105-1126, 1989.

Parrish, D. D., Millet, D. B., and Goldstein, A. H.: Increasing ozone in marine boundary layer inflow at the west coasts of North America and Europe, Atmos. Chem. Phys., 9, 1303-1323, doi:10.5194/acp-9-1303-2009, 2009.

Parrish, D. D., Law, K. S., Staehelin, J., Derwent, R., Cooper, O. R., Tanimoto, H., Volz-Thomas, A., Gilge, S., Scheel, H.-E., Steinbacher, M., and Chan, E.: Long-term changes in lower tropospheric baseline ozone concentrations at northern mid-latitudes, Atmos. Chem. Phys., 12, 11485-11504, doi:10.5194/acp-1211485-2012, 2012.

Parrish, D. D., Lamarque, J. F., Naik, V., Horowitz, L., Shindell, D. T., Staehelin, J., Derwent, R., Cooper, O. R., Tanimoto, H., Volz-Thomas, A., Gilge, S., Scheel, H.-E., Steinbacher, M., and Fröhlich, M.: Long-term changes in lower tropospheric baseline ozone concentrations: Comparing chemistry-models and observations at northern midlatitudes, J. Geophys. Res.-Atmos., 119, 5719-5736, 2014.

Pinder, R. W., Gilliland, A. B., and Dennis, R. L.: Environmental impact of atmospheric $\mathrm{NH}_{3}$ emissions under present and future conditions in the eastern United States, Geophys. Res. Lett., 35, L12808, doi:10.1029/2008GL033732, 2008a.

Pinder, R. W., Dennis, R. L., and Bhave, P. V.: Observable indicators of the sensitivity of $\mathrm{PM}<\mathrm{sub}>2.5</ \mathrm{sub}>$ nitrate to emission reductions - Part I: Derivation of the adjusted gas ratio and applicability at regulatory-relevant time scales, Atmos. Environ., 42, 1275-1286, 2008b.

Price, C., Penner, J., and Prather, M.: $\mathrm{NO}_{\mathrm{x}}$ from lightning 1: Global distribution based on lightning physics, J. Geophys. Res., 102, 5929-5941, 1997. 
Pleim, J. E.: A Combined Local and Nonlocal Closure Model for the Atmospheric Boundary Layer. Part I: Model Description and Testing, J. Appl. Meteorol. Clim., 46, 1383-1395, doi:10.1175/JAM2539.1, 2007a.

Pleim, J. E.: A Combined Local and Nonlocal Closure Model for the Atmospheric Boundary Layer. Part II: Application and Evaluation in a Mesoscale Meteorological Model, J. Appl. Meteorol. Clim., 46, 1396-1409, doi:10.1175/JAM2534.1, 2007b.

Pleim, J. E. and Gilliam, R.: An indirect data assimilation scheme for deep soil temperature in the Pleim-Xiu land surface model, J. Appl. Meteorol. Clim., 48, 1362-1376, 2009.

Pleim, J. E. and Xiu, A.: Development and testing of a surface flux and planetary boundary layer model for application in mesoscale models, J. Appl. Meteorol., 34, 16-32, 1995.

Pleim, J. E. and Xiu, A.: Development of a land surface model. Part II: Data Assimilation, J. Appl. Meteorol., 42, 1811-1822, 2003.

Richter, A., Burrows, J. P., Nues, H., Granier, C., and Niemeier, U.: Increase in tropospheric nitrogen dioxide over China observed from space, Nature, 437, 129-132, 2005.

Schumann, U. and Huntrieser, H.: The global lightning-induced nitrogen oxides source, Atmos. Chem. Phys., 7, 3823-3907, doi:10.5194/acp-7-3823-2007, 2007.

Sharma, S., Lavoué, D., Cachier, H., Barrie, L. A., and Gong, S. L.: Long-term trends of the black carbon concentrations in the Canadian Arctic. J. Geophys. Res.-Atmos., 109, D15203, doi:10.1029/2003JD004331, 2004.

Sickles II, J. E. and Shadwick, D. S.: Changes in air quality and atmospheric deposition in the eastern United States: 1990-2004, J.Geophys. Res., 112, D17302, doi:10.1029/2006JD007843, 2007.

Sillman, S.: The relation between ozone, $\mathrm{NO}_{\mathrm{x}}$ and hydrocarbons in urban and polluted rural environments, Atmos. Environ., 33, 1821-1845, 1999.

Simpson D., Fagerli, H., Jonson, J. E., Tsyro, S., Wind, P., and Tuovinen, J.: "Transboundary Acidification, Eutrophication, and Ground Level Ozone in Europe - Part I: Unified EMEP Model Description”, EMEP Status Report 2003, The Norwegian Meteorological Institute, Oslo, 25 Norway, 2003.

Tesche, T. W., Morris, R., Tonnesen, G., McNally, D., Boylan, J., and Brewer, P.: CMAQ/CAMx annual 2002 performance evaluation over the eastern United States, Atmos. Environ., 40, 49064919, 2006.

Trainer, M., Parrish, D. D., Buhr, M. P., Norton, R. B., Fehsenfeld, F. C., Anlauf, K. G., Bottenheim, J. W., Tang, Y. Z., Wiebe, H. A., Roberts, J. M., Tanner, R. L., Newman, L., Bowersox, V. C., Meagher, J. F., Olszyna, K. J., Rodgers, M. O., Wang, T., Berresheim, H., Demerjian, K. L., and Roychowdhury, U. K.: Correlation of ozone with $\mathrm{NO}_{\mathrm{y}}$ in photochemically aged air, J. Geophys. Res.-Atmos., 98, 2917-2925, 1993

Tsimpidi, A. P., Karydis, V. A., and Pandis, S. N.: Response of Inorganic Fine Particulate Matter to Emission Changes of Sulfur Dioxide and Ammonia: The Eastern United States as a Case Study, J. Air Waste Manage., 57, 1489-1498, doi:10.3155/10473289.57.12.1489, 2007.

Wakamatsu, S., Morikawa, T., and Ito, A.: Air Pollution Trends in Japan between 1970 and 2012 and Impact of Urban Air Pollution Countermeasures, Asian Journal of Atmospheric Environment, 7-4, 177-190, December 2013.
Wang, K., Zhang, Y., Jang, C., Phillips, S., and Wang, B.: Modeling intercontinental air pollution transport over the trans-Pacific region in 2001 using the Community Multiscale Air Quality modeling system, J. Geophys. Res.-Atmos., 114, D04307, doi:10.1029/2008JD010807, 2009.

Wang, S., Xing, J., Chatani, S., Hao, J., Klimont, Z., Cofala, J., and Amann, M.: Verification of anthropogenic emissions of China by satellite and ground observations, Atmos. Environ., 45, 63476358, 2011a.

Wang, S., Xing, J., Jang, C., Zhu, Y., Fu, J., and Hao, J.: Impact assessment of ammonia emissions on inorganic aerosols in east China using response surface modeling technique, Environ. Sci. Technol., 45, 9293-9300, doi:10.1021/es2022347, 2011 b.

Wang, S., Xing, J., Zhao, B., Jang, C., and Hao, J.: Effectiveness of national air pollution control policies on the air quality in metropolitan areas of China, J. Environ. Sci., 26, 13-22, 2014.

Wang, Y., Konopka, P., Liu, Y., Chen, H., Müller, R., Plöger, F., Riese, M., Cai, Z., and Lü, D.: Tropospheric ozone trend over Beijing from 2002-2010: ozonesonde measurements and modeling analysis, Atmos. Chem. Phys., 12, 8389-8399, doi:10.5194/acp-12-8389-2012, 2012.

Wild, M.: Global dimming and brightening: A review, J. Geophys. Res., 114, D00D16, doi:10.1029/2008JD011470, 2009.

Xing, J., Zhang, Y., Wang, S., Liu, X., Cheng, S., Zhang, Q., Chen, Y., Hao, J., and Wang, W.: Modeling study on the air quality impacts from emission reductions and atypical meteorological conditions during the 2008 Beijing Olympics, Atmos. Environ., 45, 1786-1798, 2011a.

Xing, J., Wang, S. X., Jang, C., Zhu, Y., and Hao, J. M.: Nonlinear response of ozone to precursor emission changes in China: a modeling study using response surface methodology, Atmos. Chem. Phys., 11, 5027-5044, doi:10.5194/acp-11-5027-2011, 2011 b.

Xing, J., Pleim, J., Mathur, R., Pouliot, G., Hogrefe, C., Gan, C.-M., and Wei, C.: Historical gaseous and primary aerosol emissions in the United States from 1990 to 2010, Atmos. Chem. Phys., 13, 7531-7549, doi:10.5194/acp-13-7531-2013, 2013.

Xiu, A. and Pleim, J. E.: Development of a Land Surface Model. Part I: Application in a Mesoscale Meteorological Model, J. Appl. Meteorol., 40, 192-209, 2001.

$\mathrm{Xu}, \mathrm{X}$. and Lin, W.: Trends of Tropospheric Ozone over China Based on Satellite Data (1979-2005), Advances in Climate Change Research, 2, 43-48, 2011.

Yamaji, K., Ohara, T., Uno, I., Tanimoto, H., Kurokawa, J. I., and Akimoto, H.: Analysis of the seasonal variation of ozone in the boundary layer in East Asia using the Community Multiscale Air Quality model: What controls surface ozone levels over Japan?, Atmos. Environ., 40, 1856-1868, 2006.

Zhang, H., Chen, G., Hu, J., Chen, S.-H., Wiedinmyer, C., Kleeman, M., and Ying, Q.: Evaluation of a seven-year air quality simulation using the Weather Research and Forecasting (WRF)/Community Multiscale Air Quality (CMAQ) models in the eastern United States, Sci. Total Environ., 473-474, 275-285, 2014.

Zhang, X., Zhang, P., Zhang, Y., Li, X., and Qiu, H.: The trend, seasonal cycle, and sources of tropospheric $\mathrm{NO}_{2}$ over China during 1997-2006 based on satellite measurement, Sci. China Ser. D, 50, 1877-1884, 2007. 
Zhang, X., van Geffen, J., Liao, H., Zhang, P., and Lou, S. J.: Spatiotemporal variations of tropospheric $\mathrm{SO}_{2}$ over China by SCIAMACHY observations during 2004-2009, Atmos. Environ., 60, 238-246, 2012.

Zhang, Y., Vijayaraghavan, K., Wen, X.-Y., Snell, H. E., and Jacobson, M. Z.: Probing into regional ozone and particulate matter pollution in the United States: 1. A 1 year CMAQ simulation and evaluation using surface and satellite data, J. Geophys. Res., 114, D22304, doi:10.1029/2009JD011898, 2009.
Zhao, B., Wang, S. X., Dong, X. Y., Wang, J. D., Duan, L., Fu, $\mathrm{X}$., Hao, J., and Fu, J.: Environmental effects of the recent emission changes in China: Implications for particulate matter pollution and soil acidification, Environ. Res. Lett., 8, 24031, doi:10.1088/1748-9326/8/2/024031, 2013. 